\title{
Gastrointestinal helminth parasites of the threatened Australasian crested grebe (Podiceps cristatus australis, Gould 1844) in New Zealand, with descriptions of Baruscapillaria kamanae n. sp. (Nematoda: Trichuridae) and Cryptocotyle micromorpha n. sp. (Trematoda: Opisthorchiidae)
}

\author{
Bronwen Presswell 1 - Jerusha Bennett \\ Received: 23 September 2021 / Accepted: 20 December 2021 / Published online: 6 February 2022 \\ (C) The Author(s) 2022
}

\begin{abstract}
The Australasian crested grebe Podiceps cristatus australis, Gould 1844 is restricted to Australia and New Zealand, where it is listed as Threatened and Nationally Vulnerable. For the first time in New Zealand, we report on the parasitic helminths infecting three individuals from Lake Wanaka, Otago, using morphological and molecular tools. Seven helminth species were found in the gastrointestinal tract: 2 nematodes (Contracaecum ovale and Baruscapillaria kamanae n. sp.), 4 trematodes (Australapatemon minor, Cryptocotyle micromorpha n. sp., Tylodelphys darbyi and Neopetasiger neocomensis), and 1 cestode (Confluaria pseudofurcifera). Except for $T$. darbyi, all are new records for New Zealand. A change of orthography is proposed for Neopetasiger neocomensis and N. pseudoneocomensis. Cryptocotyle micromorpha $\mathbf{n}$. sp. (Opisthorchiidae) is distinguished from similar species by its small size, wholly extracaecal vitellaria and anteriorly looped uterus. Baruscapillaria kamanae n. sp. (Trichuridae) is distinguished from other freshwater species by a combination of vulva and spicule morphology. The helminth parasites found here are mostly the same as those from the grebe in the northern hemisphere, indicating that they have been carried with the host species in its spread to Australasia. However, the
\end{abstract}

B. Presswell $(\bowtie) \cdot J$. Bennett

Department of Zoology, University of Otago,

PO Box 56, Dunedin, New Zealand

e-mail: bpresswell@hotmail.com parasite fauna may be depauperate due to a diminishing reservoir of intermediate hosts in that geographical migration.

\section{Introduction}

The great crested grebe (Podiceps cristatus Linnaeus) (Podicipediformes) has a broad distribution in Europe, Asia and Africa, but the subspecies P. cristatus australis Gould occurs only in Australia and New Zealand, where it is listed as Threatened and Nationally Vulnerable under the New Zealand Threat Classification System. In addition, the species is considered taonga ("treasure") by Maori and is fully protected. Crested grebes arrived in New Zealand over 10,000 years ago (Jensen and Snoyink, 2005), and were once widespread throughout the country. However, they are now restricted to a number of lakes in the South Island, and a survey of 2005 found the largest numbers in Lake Hayes, Otago, and Lake Heron, Canterbury (Jensen and Snoyink, 2005). In New Zealand grebes face threats due to predation by introduced mammals, loss of shore line nesting habitat and disturbances from human activities (Jensen and Snoyink, 2005). The population at Lake Wanaka, Otago, however, has increased by 300 birds in recent years (Darby, 2021), thanks to the skill and dedication of John Darby. The crested grebe is the only grebe 
species currently to occur in the South Island of New Zealand.

Despite its threatened status, knowledge of some aspects of Australasian crested grebe biology is still sparse. In particular, the parasite fauna of great crested grebes in New Zealand has never been examined. The benefits of discovery and identification of an animal's parasites are well established; including data pertaining to host health, feeding habits, distribution, potential competition with other host species, and to compare with other grebe species (see Storer, 2000). Parasites can be disease causing agents too, making their study especially important for threatened host species.

Great crested grebe parasites are well documented in northern hemisphere populations. Storer (2000) listed a total of 102 helminth species (Trematoda, 46; Cestoda, 31; Acanthocephala, 2; Nematoda, 23), since which can be added a further 5 records from the literature (2 trematodes; 2 cestodes; 1 nematode) (Fain, 1956; Vasileva et al., 2003; Mutafchiev \& Georgiev, 2008). Australia has geographically the closest population and is the probable origin of the New Zealand crested grebes. There are nine helminth species recorded from Australia (4 trematodes; 1 cestode; 4 nematodes), although only 5 are identified to species level and all reports are from just two studies (Johnston \& Mawson, 1949; Mawson et al., 1986), so the parasite fauna from Australia is also very little known.

Due to the protected and threatened nature of crested grebes in New Zealand, it has not been possible to investigate the parasite fauna of these birds until now. However, between January 2017 and January 2020 three dead individuals were collected from Lake Wanaka, allowing the first investigation of the parasites of the New Zealand population of this subspecies. This study represents a record of the helminths found in these three grebe specimens, all of which are new records for New Zealand, and two of which are described as new species. We present brief morphological data for known species, and molecular data where required to confirm species identity, as well as descriptions of two new species.

\section{Materials and methods}

Morphological data

Three Australasian crested grebes (Podiceps cristatus australis Gould) were found dead near the marina breeding area at Lake Wanaka, Otago in January 2017, January 2018 and January 2021. Deceased birds were donated by John Darby, conservator and protector of Lake Wanaka crested grebes. A white-faced heron (Egretta novaehollandiae (Latham)) was also found freshly dead at a nearby site in June 2018. A blackbacked gull (Larus dominicanus Lichtenstein) with comparable helminth infections was one of many dead birds donated by the Dunedin Wildlife Hospital from the Otago region. Birds were dissected fresh, and helminths were collected and preserved in $70 \%$ ethanol for whole-mount, $96 \%$ ethanol for genetic analyses and $4 \%$ buffered formalin for later SEM imaging.

Nematode specimens were cleared in lactophenol as temporary mounts for light microscopy. Cestode and trematode specimens were stained using acetic acid iron carmine, dehydrated in an ethanol series, cleared in clove oil and permanently mounted with Canada balsam.

Measurements were made using ImageJ software (Wayne Rasband, NIH, USA) from photographs taken on an Olympus BX51 compound microscope mounted with DP25 camera attachment. All measurements are in micrometres unless otherwise indicated, and in descriptions are given as range, followed by mean in parentheses, where numbers permit. Drawings were made with the aid of a drawing tube mounted on an Olympus compound microscope, or from photographic series.

Parasites were identified to the lowest taxonomic level possible. Taxa unfamiliar to the authors were identified using morphological keys such as Khalil et al. (1994), Gibbons (2010), Gibson et al. (2002), Bray et al. (2008), and original species descriptions. Some of the material reported in this article was described by the first author in a previous paper (i.e. Tylodelphys darbyi, Presswell \& Blasco-Costa 2020).

Specimens of each species, when available, were chosen for scanning electron microscopy (SEM) and preserved in $4 \%$ buffered formalin. These specimens were transferred to $2.5 \%$ gluteraldehyde in $0.1 \mathrm{M}$ phosphate buffer, then post-fixed in $1 \%$ osmium 
tetroxide and dehydrated through a gradient series of ethanols, critical-point dried in a CPD030 BalTec critical-point dryer (BalTec AG, Balzers, Liechtenstein) using carbon dioxide, mounted on aluminium stubs, and sputter coated with gold/palladium (60:40) to a thickness of $10 \mathrm{~nm}$ in an Emitech K575X Peltiercooled high-resolution sputter coater (EM Technologies, Ashford, Kent, UK). The specimens were viewed with a JEOL $6700 \mathrm{~F}$ field emission scanning electron microscope (JEOL Ltd., Tokyo, Japan) or Zeiss Sigma VP variable-pressure scanning electron microscope (Carl Zeiss Inc., Oberkocken, Germany) at the Otago Centre for Electron Microscopy (OCEM, University of Otago, New Zealand). Voucher specimens of new species were deposited in Te Papa Museum, Wellington, New Zealand, under accession numbers W.003609-3614.

Molecular data and analyses

Specimens of each species were chosen for DNA sequencing. Genomic DNA was extracted using the DNeasy ${ }^{\circledR}$ Blood \& Tissue Kit (Qiagen, Hilden, Germany) according to the manufacturer's protocol. For cestodes and trematodes a partial fragment of $28 \mathrm{~S}$ rRNA gene was amplified using T16 and T30 primers (Harper \& Saunders, 2001) and conditions of $94^{\circ} \mathrm{C}$ for $5 \mathrm{~min}, 38 \mathrm{cycles}$ of $94^{\circ} \mathrm{C}$ for $30 \mathrm{sec}, 45^{\circ} \mathrm{C}$ for $30 \mathrm{sec}$ and $72^{\circ} \mathrm{C}$ for $2 \mathrm{~min}$, and $72^{\circ} \mathrm{C}$ for $7 \mathrm{~min}$. Additionally, cox 1 was amplified when possible, using primers JB3 (Bowles et al., 1992) and trem.cox.rrnl (KrálováHromadová et al., 2001) and conditions of $95^{\circ} \mathrm{C}$ for $2 \mathrm{~min}, 40$ cycles of $95^{\circ} \mathrm{C}$ for $30 \mathrm{sec}, 48^{\circ} \mathrm{C}$ for $40 \mathrm{sec}$ and $72^{\circ} \mathrm{C}$ for $1 \mathrm{~min}$, and $72^{\circ} \mathrm{C}$ for $10 \mathrm{~min}$. For nematodes, either the $28 \mathrm{~S}, 18 \mathrm{~S}$ or ITS1 genes were targeted using 28SF and 28SR (Nadler \& Hudspeth, 2000), Nem18SF and Nem18SR (Wood et al., 2013) and SS1 and NC13R (Shamsi et al., 2008) primers respectively. The 28S PCR conditions consisted of $94^{\circ} \mathrm{C}$ for $5 \mathrm{~min}, 38$ cycles of $94^{\circ} \mathrm{C}$ for $30 \mathrm{sec}, 52^{\circ} \mathrm{C}$ for $30 \mathrm{sec}$ and $72^{\circ} \mathrm{C}$ for $1 \mathrm{~min}$, and $72^{\circ} \mathrm{C}$ for $10 \mathrm{~min}$. The $18 \mathrm{~S}$ and ITS PCR conditions followed Wood et al. (2013) and Shamsi et al. (2008). All PCR products were cleaned using EXOSAP-TMTM Express PCR Product Cleanup Reagent (USB Corporation, Cleveland, OH, USA), following manufacturer's instructions. Sanger sequencing by capillary electrophoresis was performed by the Genetic Analysis Service,
Department of Anatomy, University of Otago (Dunedin, New Zealand).

Sequences were used in BLASTn searches on GenBank ${ }^{\circledR}$ to establish a preliminary identification. Sequences were imported into Geneious Prime®v1.2, trimmed using the trim function with default parameters, and manually edited for incorrect or ambiguous base calls. A contiguous sequence was assembled for each sequence, alignments were created separately for each species sequenced, and genetic divergences were calculated in MEGA v.10 comparing between closely related species to confirm identity. Newly generated sequences are listed in Table 1, with their associated GenBank accession numbers.

\section{Results}

In total, 7 parasite species were recovered from three grebe specimens: 2 nematodes, 4 trematodes and 1 cestode. All three grebe individuals were infected with at least one species of parasite. Except for the capillarid nematode, and trematode Australapatemon minor, each parasite species was found in all of the grebe specimens. The parasite with the highest mean intensity was a hitherto undescribed species of Cryptocotyle, found in many hundreds of individuals per host (infection data are summarised in Table 2).

\section{NEMATODA Cobb, 1932 \\ Ascaridida Skrjabin et Schulz, 1940 \\ Ascaridoidea Baird, 1853 \\ Anisakidae Railliet \& Henry, 1912 \\ Contracaecum Railliet \& Henry, 1912}

Type species: Ascaris spiculigera Rudolphi, 1809

Contracaecum ovale (Linstow, 1907) Baylis, 1920.

Fig. 1a-d

Synonyms: Ascaris ovalis Linstow, 1907; C. nehli Karokhin, 1949; C. podicipitis Johnston \& Mawson, 1949; C. ruficolle Vuylsteke, 1953; C. spasskii Mozgovoi, 1959.

All three grebes, and the single white-faced heron, were infected with specimens of Contracaecum Railliet \& Henry, 1912, identifiable by their prominent lips without dentigerous ridges, presence of interlabia, intestinal caecum, and reduced ventriculus with solid 
Table 1 GenBank Accession numbers of newly generated sequences of helminths from Australasian crested grebe and white-faced heron in brackets in Otago, New Zealand.

\begin{tabular}{|c|c|c|c|c|}
\hline \multirow[t]{2}{*}{ Parasite Species } & \multicolumn{4}{|l|}{ GenBank Accession } \\
\hline & $18 \mathrm{~S}$ & $28 \mathrm{~S}$ & ITS1 & $\operatorname{cox} 1$ \\
\hline \multicolumn{5}{|l|}{ Nematoda } \\
\hline Contracaecum ovale & OL470519 (OL470521) & OL470528 & OL470520 & \\
\hline Baruscapillaria kamanae n. sp. & & OL470526 & & \\
\hline \multicolumn{5}{|l|}{ Trematoda } \\
\hline Tylodelphys darbyi & & OL470527 & & OL504982 \\
\hline Cryptocotyle micromorpha $\mathbf{n}$. sp. & & OL470523 & & OL504983 \\
\hline Neopetasiger neocomensis & & OL470525 & & \\
\hline \multicolumn{5}{|l|}{ Cestoda } \\
\hline Confluaria psudofurcifera & & OL470524 & & \\
\hline
\end{tabular}

Table 2 Prevalence and intensity data of helminths found in Australasian crested grebes $(n=3)$, and heron $(n=1)$ from Lake Wanaka, Otago.

\begin{tabular}{|c|c|c|c|}
\hline & \multicolumn{2}{|c|}{ Australasian crested grebe } & \multirow{2}{*}{$\begin{array}{l}\text { White- } \\
\text { faced } \\
\text { heron } \\
\text { Intensity }\end{array}$} \\
\hline & $\begin{array}{l}\text { prevalence } \\
\text { (no. birds) }\end{array}$ & $\begin{array}{l}\text { Intensity } \\
\text { range }\end{array}$ & \\
\hline \multicolumn{4}{|l|}{ Nematoda } \\
\hline $\begin{array}{l}\text { Contracaecum } \\
\text { ovale }\end{array}$ & 3 & $24-122$ & 245 \\
\hline $\begin{array}{l}\text { Baruscapillaria } \\
\text { kamanae } \mathbf{n} . \mathbf{s p .}\end{array}$ & 2 & $1-13$ & 1 \\
\hline \multicolumn{4}{|l|}{ Trematoda } \\
\hline $\begin{array}{l}\text { Australapatemon } \\
\quad \text { minor }\end{array}$ & 1 & 3 & - \\
\hline Tylodelphys darbyi & 3 & $2-22$ & 4 \\
\hline $\begin{array}{l}\text { Cryptocotyle } \\
\text { micromorpha } \mathbf{n} . \\
\text { sp. }\end{array}$ & 3 & $700-1000 \mathrm{~s}$ & 150 \\
\hline $\begin{array}{l}\text { Neopetasiger } \\
\text { neocomensis }\end{array}$ & 3 & $40-145$ & 800 \\
\hline \multicolumn{4}{|l|}{ Cestoda } \\
\hline $\begin{array}{l}\text { Confluaria } \\
\text { pseudofurcifera }\end{array}$ & 3 & $1-40+$ & - \\
\hline
\end{tabular}

posterior appendix. The worms (numbering 24, 53 and 122 in the three birds respectively) were mainly concentrated in the stomach, with some in the upper intestine. Infections included L4 larvae and adults, with a large size range from $11 \mathrm{~mm}$ to $28 \mathrm{~mm}$. Males were smaller than females, and metrics fell within with the ranges given by Galeano \& Tanzola (2012) and other references for Contracaecum ovale, including those of synonymous species (see below). Contracaecum ovale was described (as Ascaris ovalis) from specimens recovered from Podiceps cristatus in Germany. Characteristic features are indicated in Fig. 1a-d and a brief description follows.

Males $(n=5$, plus 2 part specimens, Fig. $1 \mathrm{~b}$ and d): body length $13.3-18.2 \mathrm{~mm}$; maximum body width $0.47-0.64 \mathrm{~mm}$; distance from anterior end to nerve ring $0.32-0.40 \mathrm{~mm}(\mathrm{n}=4)$; oesophagus total length 2.4-3.4mm; intestinal caecum length $1.6-1.9 \mathrm{~mm}$ (n $=3$ ); spicules equal or slightly subequal, length $1.04-2.38 \mathrm{~mm}$ ( $\mathrm{n}=7$ pairs); tail length $0.22-0.30$ $\mathrm{mm}$. Precloacal papillae 27-30 pairs $(n=2)$. Postcloacal papillae five pairs of variable placement (most common arrangement shown in Fig. 1b): first pair double, two subventral pairs, two sublateral pairs; one pair lateral phasmids level with slight constriction near tail tip.

Female ( $\mathrm{n}=8$, Fig. 1c): body length 10.6-27.6mm; maximum body width $0.46-1.06 \mathrm{~mm}$; distance from anterior end to nerve ring $0.79-1.21 \mathrm{~mm}(\mathrm{n}=2)$; oesophagus total length $2.8-5.6 \mathrm{~mm}(\mathrm{n}=6)$; intestinal caecum length $1.9-3.5 \mathrm{~mm}(\mathrm{n}=4)$; vulva in anterior half of the body, 29-34\% body length; postanal length $0.34-0.62 \mathrm{~mm}$; eggs $60-68 \times 46-56$. 

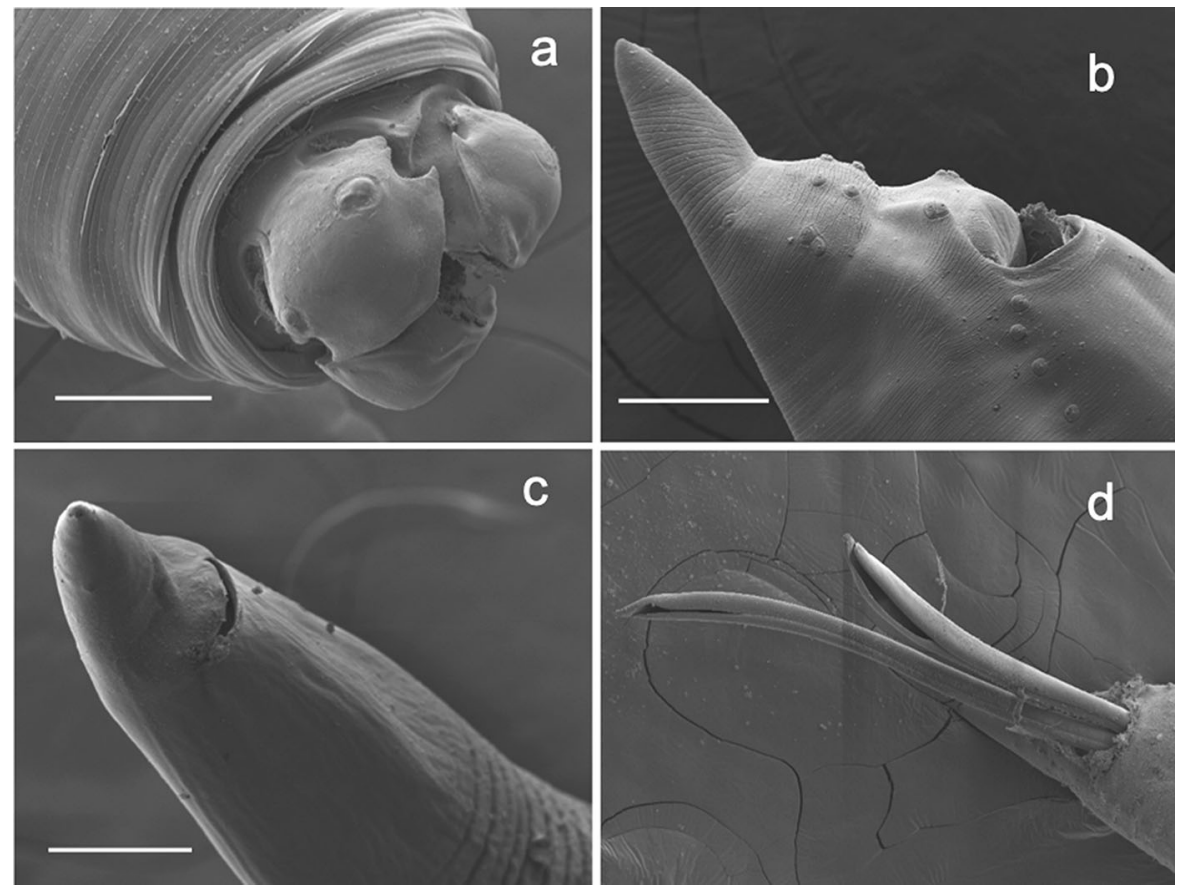

Fig. 1 Scanning electron micrographs of nematode Contracaecum ovale from crested grebe, Lake Wanaka. (a) anterior end showing lips and reduced interlabia, (b) male posterior end showing caudal papillae, (c) female posterior end, (d) male posterior end showing spicules. Scale a, c, d = $100 \mu \mathrm{m} ; \mathrm{b}=50 \mu \mathrm{m}$

\section{Remarks}

Although the speciose genus Contracaecum has a confused and somewhat unreliable taxonomic history, species found mainly in grebes have distinctive characters that set them apart from other, mainly marine, species (see Discussion). Our specimens were therefore compared against all other species found in grebes, most of which we recognise as synonyms of $C$. ovale.

DNA sequences were obtained for the $18 \mathrm{~S}$ and ITS1 markers. Closest BLASTn hits gave a larval Contracaecum species from a freshwater fish in India for $18 \mathrm{~S}$ (99.63\% similarity [MG696304]). It seems highly likely that the Indian specimens belong to the freshwater 'grebe' group of species (see Discussion). ITS1 produced a BLASTn result that included many available Contracaecum sequences but no other sequences were available for known 'grebe' species, leaving molecular identification and exploration of the relationships of the 'grebe' species in abeyance for the time being. The sequence of $18 \mathrm{~S}$ was identical to those of worms from the white-faced heron.

\section{Enoplida Filipjev, 1929 \\ Trichinelloidea Ward, 1907 \\ Trichuridae Ransom, 1911 \\ Baruscapillaria Moravec, 1982}

Type species: Capillaria obsignata Madsen, 1945 by original designation.

Baruscapillaria kamanae n. sp. Figs. 2a-f, 3a-f

A total of 16 specimens of a hair-like nematode was found in the stomachs of two grebes, of which 6 were male, 7 were female and 3 were indeterminate fragments. Two specimens of matching morphology were also found in the white-faced heron. Most of these delicate nematodes were broken, allowing some measurements, but two entire males and two entire females remained to allow body length measurements to be taken. In having a male with caudal alae absent, 

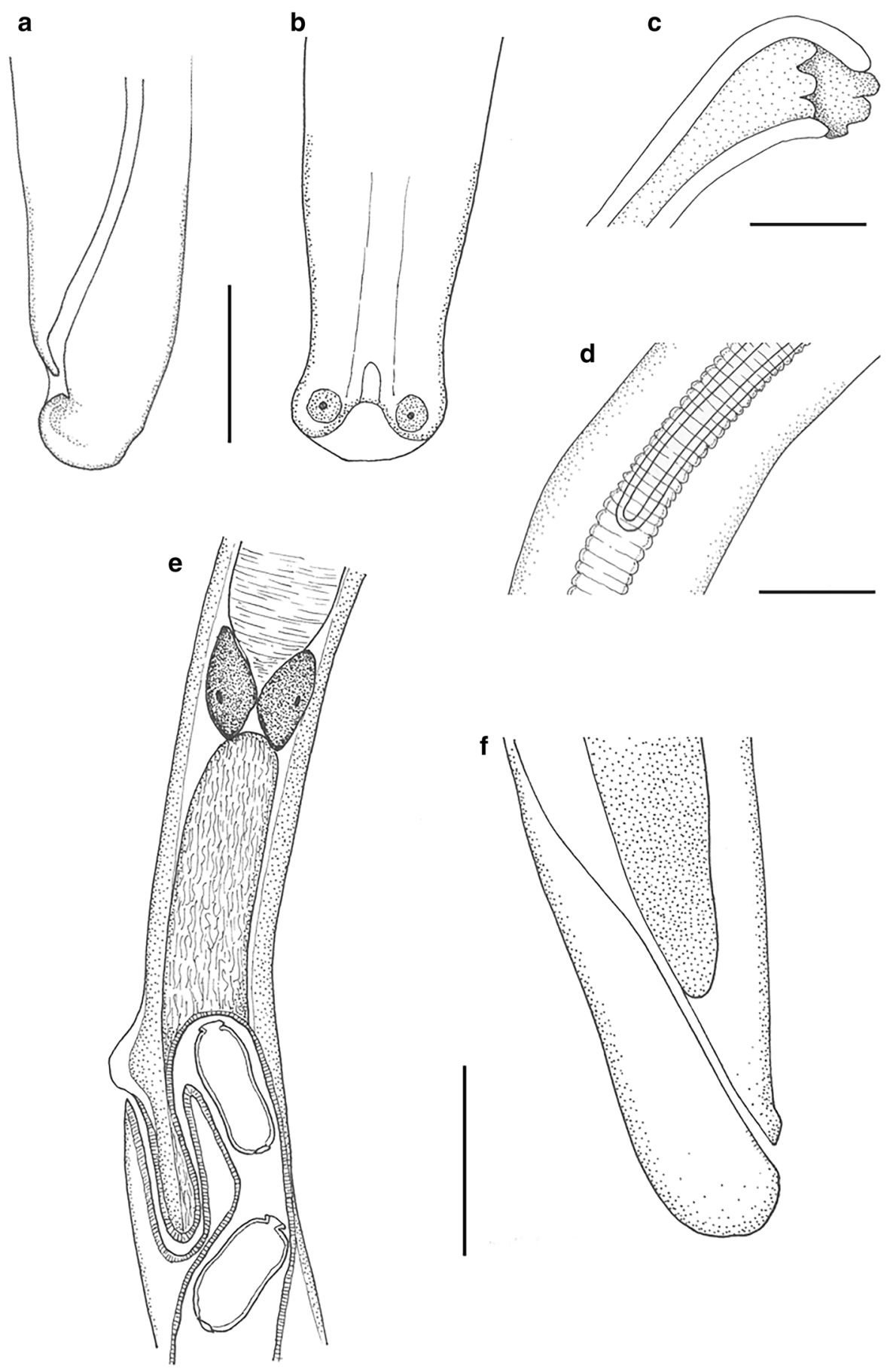

Fig. 2 Baruscapillaria kamanae n. sp. from crested grebe, Lake Wanaka. (a) male posterior lateral view, (b) male posterior ventral view, (c) spicule proximal end, (d) spicule distal end, (e) posterior end of stichosome, showing two large glandular cells, vulva and anterior loop of vagina, (f) female posterior end. Scale a, b, c, d = $30 \mu \mathrm{m}$; e, $\mathrm{f}=50 \mu \mathrm{m}$

pseudobursa with two small, rounded lobes, a long single spicule with aspinous spicule sheath, and presence of bacillary bands, the specimens conformed to the diagnosis of genus Baruscapillaria (Gibbons 2010). A description is given below and comparative morphometrics are given for Baruscapillaria kamanae 

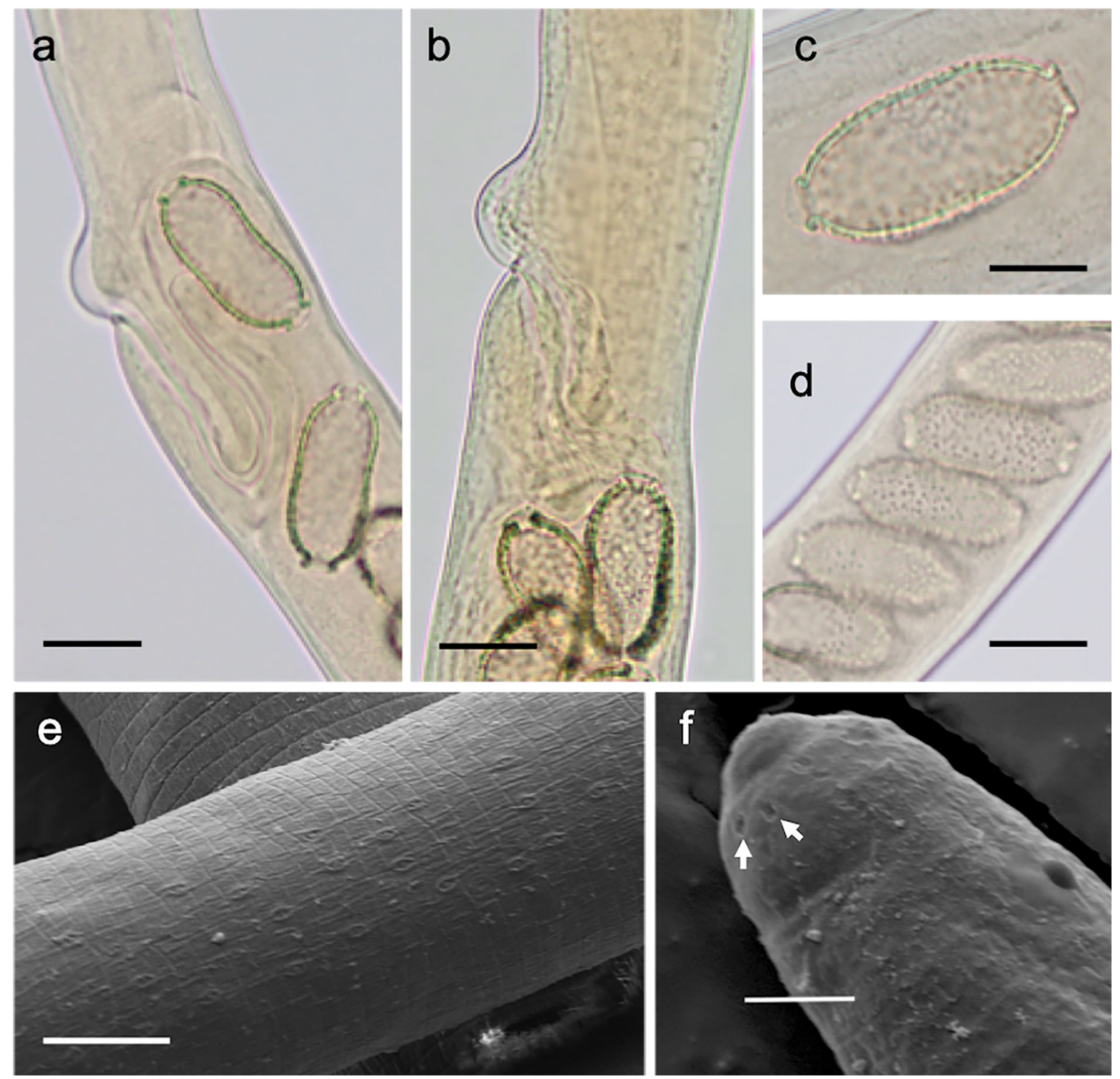

Fig. 3 Baruscapillaria kamanae n. sp. from crested grebe, Lake Wanaka. (a) vagina with anterior loop, (b) vagina without anterior loop, (c) single egg in utero, showing polar plugs, (d) eggs in utero showing punctate surface, (e) mid-body cuticle showing bacillary

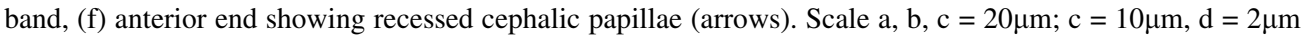

n. sp. and other species from freshwater bird hosts (Table 3).

\section{Description}

\section{General}

Body filiform; very long and thin, tapering to anterior end, widest along length of intestine. Sexually dimorphic; males smaller than females. Lateral bacillary bands present but very indistinct, number and extent not clear. Head end narrow, rounded; oral aperture terminal, slit-like, oriented dorso-ventrally. Cephalic papillae arranged around mouth in two circles, each with six recessed papillae (Fig. 3f) Muscular oesophagus long; nerve-ring indistinct. Stichosome formed by single row of stichocytes; stichocytes long, subdivided into numerous annuli. 
Table 3 Measurements of Baruscapillaria species infecting freshwater birds.

\begin{tabular}{|c|c|c|c|c|c|c|c|c|c|c|c|c|}
\hline \multirow[b]{2}{*}{ Authority } & \multicolumn{4}{|c|}{ kamanae n. sp. } & \multicolumn{2}{|c|}{ herodiae } & \multicolumn{2}{|l|}{$m e r g i^{\mathrm{a}}$} & \multicolumn{2}{|c|}{ podicipitis $^{\mathrm{a}}$} & \multicolumn{2}{|c|}{ ryjikovi $^{\mathrm{a}}$} \\
\hline & & & & & \multicolumn{2}{|c|}{$\begin{array}{l}\text { (Boyd, 1966) } \\
\text { Moravec } \\
1982\end{array}$} & \multicolumn{2}{|c|}{$\begin{array}{l}\text { (Madsen, 1945) Baruš } \\
\text { \& Sergejeva, } 1990\end{array}$} & \multicolumn{2}{|c|}{$\begin{array}{l}\text { (Yamaguti, } \\
1941) \text { Moravec } \\
1982\end{array}$} & \multicolumn{2}{|c|}{$\begin{array}{l}\text { (Borgarenko \& } \\
\text { Daiya, 1972) } \\
\text { Moravec 1982 }\end{array}$} \\
\hline \multirow[t]{3}{*}{$\begin{array}{l}\text { Hosts } \\
\text { Locality }\end{array}$} & \multicolumn{4}{|c|}{ Podiceps cristatus australis } & \multicolumn{2}{|c|}{ Ardea spp. } & \multicolumn{2}{|c|}{$\begin{array}{l}\text { Gaviiformes, } \\
\text { Podicipediformes, } \\
\text { Ciconiiformes, } \\
\text { Anseriformes }\end{array}$} & \multicolumn{2}{|c|}{$\begin{array}{l}\text { Podiceps } \\
\text { cristatus, } P . \\
\text { auritus, } P . \\
\text { nigricollis, } P \text {. } \\
\text { ruficollis.; } \\
\text { Anseriformes; } \\
\text { Lariformes }\end{array}$} & \multicolumn{2}{|c|}{$\begin{array}{l}\text { Podiceps } \\
\text { nigricollis, } P . \\
\text { griseigena, } P . \\
\text { ruficollis }\end{array}$} \\
\hline & \multicolumn{4}{|l|}{$\mathrm{NZ}$} & \multicolumn{2}{|l|}{ USA } & \multicolumn{2}{|c|}{ Europe; Russia; USA } & \multicolumn{2}{|c|}{$\begin{array}{l}\text { E. Europe; East } \\
\text { Asia, Japan }\end{array}$} & \multicolumn{2}{|c|}{$\begin{array}{l}\text { Europe; Russia } \\
\text { Asia }\end{array}$} \\
\hline & M & $\mathrm{n}$ & $\mathrm{F}$ & $\mathrm{n}$ & M & $\mathrm{F}$ & M & $\mathrm{F}$ & M & $\mathrm{F}$ & M & $\mathrm{F}$ \\
\hline $\begin{array}{l}\text { Body length (mm) } \\
\text { [BL] }\end{array}$ & $\begin{array}{r}15.3- \\
15.8\end{array}$ & 2 & $23.9-24.4$ & 2 & 8.3 & 15.3 & $\begin{array}{l}6.8- \\
10.5\end{array}$ & $13.7-16.6$ & $6.3-9.0$ & $\begin{array}{l}6.8- \\
10.1\end{array}$ & $\begin{array}{r}18.4- \\
24.2\end{array}$ & $\begin{array}{r}17.9- \\
32.3\end{array}$ \\
\hline Body width & $45-55$ & 3 & $76-86$ & 3 & $32-40$ & 39 & $48-57$ & $55-68$ & $44-55$ & $44-69$ & $50-60$ & $49-65$ \\
\hline Body length/width & $\begin{array}{l}289- \\
363\end{array}$ & 2 & 278-318 & 2 & $207 *$ & $392 *$ & $\begin{array}{l}142- \\
184 *\end{array}$ & $244-249 *$ & $\begin{array}{l}143- \\
163 *\end{array}$ & $\begin{array}{l}148- \\
154^{*}\end{array}$ & $\begin{array}{l}368- \\
403^{*}\end{array}$ & $\begin{array}{l}365- \\
496^{*}\end{array}$ \\
\hline $\begin{array}{l}\text { Oesophagus } \\
\text { length (mm) }\end{array}$ & 3.9 & 2 & $7.5-10.3$ & 2 & 3.7 & 6.7 & $3.6-4.4$ & $5.3-6.5$ & $3.7-4.3$ & $\begin{array}{r}3.6- \\
5.2\end{array}$ & $\begin{array}{r}10.9- \\
13.0\end{array}$ & $\begin{array}{l}7.6- \\
11.3\end{array}$ \\
\hline $\begin{array}{l}\text { BL/Oesophagus } \\
\text { length }\end{array}$ & 2.6 & 1 & $2.3-3.3$ & 2 & $2.2^{*}$ & $2.3^{*}$ & $\begin{array}{l}1.9- \\
2.4^{*}\end{array}$ & $2.6^{*}$ & $1.7-2.0$ & 1.9 & $1.9-2.0$ & 2.7 \\
\hline $\begin{array}{l}\text { End stichosome to } \\
\text { vulva }\end{array}$ & - & & $107-149$ & 3 & - & 30 & - & short & - & $60^{\mathrm{b}}$ & - & $\begin{array}{r}150- \\
170\end{array}$ \\
\hline $\begin{array}{l}\text { Vulvar } \\
\text { appendange }\end{array}$ & - & & $\begin{array}{l}\text { small } \\
\text { swelling }\end{array}$ & & - & $\mathrm{NO}$ & - & $\begin{array}{l}\text { cup-like } \\
\text { swelling }\end{array}$ & - & $\mathrm{NO}$ & - & $\mathrm{NO}$ \\
\hline Egg length & - & & $45-53$ & 20 & - & $\begin{array}{r}46- \\
52\end{array}$ & - & $48-53$ & - & $42-48$ & - & $40-53$ \\
\hline Egg width & - & & $20-24$ & 20 & - & $\begin{array}{l}15- \\
26\end{array}$ & - & $23-28$ & - & $16-22$ & - & $20-29$ \\
\hline Spicule length & $\begin{array}{r}1486- \\
1495\end{array}$ & 2 & - & & 1250 & - & $\begin{array}{r}1100- \\
1250\end{array}$ & - & $\begin{array}{r}630- \\
730\end{array}$ & - & $\begin{array}{r}2200- \\
2300\end{array}$ & - \\
\hline $\begin{array}{l}\text { Spicule proximal } \\
\text { end }\end{array}$ & $25-27$ & 3 & - & & NG & - & $17-20$ & - & $11-16$ & - & $23-26$ & - \\
\hline $\begin{array}{l}\text { Spicule length/BL } \\
\%\end{array}$ & 9.35 & 1 & - & & $15.06^{*}$ & - & $\begin{array}{l}11.9- \\
16.2 *\end{array}$ & - & $\begin{array}{l}8.1- \\
10.0 *\end{array}$ & - & $\begin{array}{r}14.2- \\
17.6\end{array}$ & - \\
\hline
\end{tabular}

* Measurements calculated from figures in original source. ${ }^{a}$ Measurements taken from Baruš et al. (1978) as original description is unavailable or gives limited data. ' Data from Yamaguti's (1941) original description. NG, Not Given in original source.

Two large glandular cells present at junction of stichosome and intestine (Fig. 2e).

Male (2 entire and 4 part specimens). Body length (BL) $15.2-15.8 \mathrm{~mm}$, maximum width 51-55. Width of lateral bacillary band 25 (Fig. 3e). Entire oesophagus length $8.4 \mathrm{~mm}$ (53\% of BL); junction of muscular oesophagus and stichostome not discernible, number of stichocytes not determined. Spicule well sclerotised, smooth, length 1.48-1.49 mm; proximal end expanded (23 wide) with rough protruberances, distal end rounded (9 wide) (Fig. $2 \mathrm{c}$ and d). Spicular sheath aspinous, with strong transverse striations. Caudal end with small membranous bursa supported by two lateral lobes each bearing ventrally projecting papilla; 
pseudobursa width in ventral view 30 , width in lateral view 23 (Fig. 2a and b).

Female ( 2 entire and 4 part specimens). Body length (BL) 23.9-24.3 mm, maximum width 78-86. Width of lateral bacillary band $25(\mathrm{n}=1)$. Oesophagus length $7.5-10.2 \mathrm{~mm}$ (31-43\% of BL); junction of muscular oesophagus and stichostome not discernible, number of stichocytes not determined. Vulva situated posterior to end of stichosome; distance between them 107-149. Anterior lip of vulva with small, rounded elevation; vulvar appendage absent. Vagina short, muscular, 68-120 long; initially directed posteriorly, but in some specimens with secondary anteriorly directed loop reaching level with or anterior to vulval opening (Fig. 2e, 3a and b). Eggs arranged in one to two rows; straight-sided or waisted oval, walls thickness 3; fully-developed eggs 45-53 long (including polar plugs) x 20-24 wide. Mature eggs with conspicuously punctate surface and protruding polar plugs (Fig. 3c and d), punctations less pronounced and polar plugs not protruding in immature eggs. Polar plug thickness 3, width 12. Anus subterminal; tail rounded, 12-13 long (Fig. 2f).

\section{Taxonomic summary}

Type host. Australasian crested grebe Podiceps cristatus australis Gould (Aves, Podicipediformes, Podicipedidae).

Other host. White-faced heron, Egretta novaehollandiae (Latham) (Aves, Pelicaniformes, Ardeidae).

Site of infection. Intestine

Type locality. Mou Waho Island, Lake Wanaka, New Zealand (44.55 S, 169.08 E)

Other locality. Roy's Bay, Lake Wanaka, New Zealand (44.39 S, 168.59 E)

Intensity. 15, 1 and 0 in three birds.

Type specimens. Te Papa Museum, Wellington, New Zealand : Holotype (W.003613), Allotype (W.003614)

Genbank accession number. OL470526 (one partial 28S sequence)

Zoobank reference. urn:lsid:zoobank.org:act:2A6D33AD-DB58-48D3-AA8B-

B97C6A959E37

Etymology. The species name, a noun in the genitive case, is derived from the Maori name for the crested grebe, kāmana.
Partial sequence of $28 \mathrm{~S}$ was obtained for a specimen from one grebe. In BLASTn searches, the sequence showed greatest similarity with Aoncotheca paranalis (92.76\% similarity over 445bp), Capillaria plica (91.22\%) and Pearsonema plica (88.85\% similarity). There are no overlapping sequences for Baruscapillaria spp. on GenBank, so these results tell us little at this time except for confirming the familial placement. Attempts to amplify $18 \mathrm{~S}$ were unsuccessful.

\section{Remarks}

There are currently 21 species of Baruscapillaria that appear valid in the literature (Baruš \& Sergejeva, 1990). Of these, 7 species are found in mammals, 6 in terrestrial birds and 4 in marine birds. The remaining 4 species infect freshwater birds, namely $B$. herodiae (Boyd, 1966) Moravec, 1982 in Ardea spp., B. mergi (Madsen, 1945) Baruš \& Sergejeva, 1990 in Gaviiformes, Podicipediformes, Ciconiiformes and Anseriformes, B. podicipitis (Yamaguti, 1941) Moravec, 1982 in Podicipediformes, Anseriformes and Lariformes, and B. ryjikovi (Borgarenko \& Daiya, 1972) Moravec, 1982 in Podicipediformes.

Compared to Baruscapillaria kamanae n. sp., $B$. herodiae is considerably smaller in body length and spicule length, has no vulval swelling and a very short distance between vulva and stichosome (Boyd, 1966). B. mergi also has a smaller body length, as well as a small 'cup-like' vulval appendage, and fine striations on the spicule (Madsen, 1945). B. podicipitis is notably smaller in body length and spicule length, with a very short distance between vulva and stichosome and lemon-shaped eggs (Yamaguti, 1941). Baruscapillaria ryjikovi is closest to B. kamanae $\mathbf{n}$. sp. in size, as well as being a grebe-specific species, but it is longer than B. kamanae n. sp. with a longer spicule, and has no vulvar swelling (Baruš \& Sergejeva, 1990). An unnamed species of Baruscapillaria was reported by Presswell and Bennett (2021) from black shag Phalacrocorax carbo novaehollandiae (Stephens) in Otago. Those specimens were smaller than B. kamanae n. sp. with a shorter spicule. In addition to the anterior loop of the vagina, the above characters distinguish the New Zealand grebe specimens from other known species. 
TREMATODA Rudolphi, 1808

Diplostomida Olson, Cribb, Tkach, Bray, and

Littlewood, 2003

Diplostomoidea Poirier, 1886

Strigeidae Railliet, 1919

Australapatemon Sudarikov, 1959

Type species: Hemistomum intermedium Johnston, 1904

Australapatemon minor (Yamaguti, 1933) Yamaguti, 1971 Fig. 4

Synonyms: Apatemon minor Yamaguti, 1933; Apatemon gracilis minor (Yamaguti, 1933) Dubois, 1953; Australapatemon skrjabini Ryzhikov, Leonov et Tzimbaluk, 1964

Three adult specimens of this species were found in the upper intestine of a single grebe.

In possessing a bipartite body, testes tandem and irregular, vitellarium confined to hindbody and genital cone large with long, rugose hermaphroditic duct, the specimens conform to the diagnosis of genus Australapatemon Sudarikov, 1959 as emended by BlascoCosta et al. (2016). We include a brief description below for future comparison.

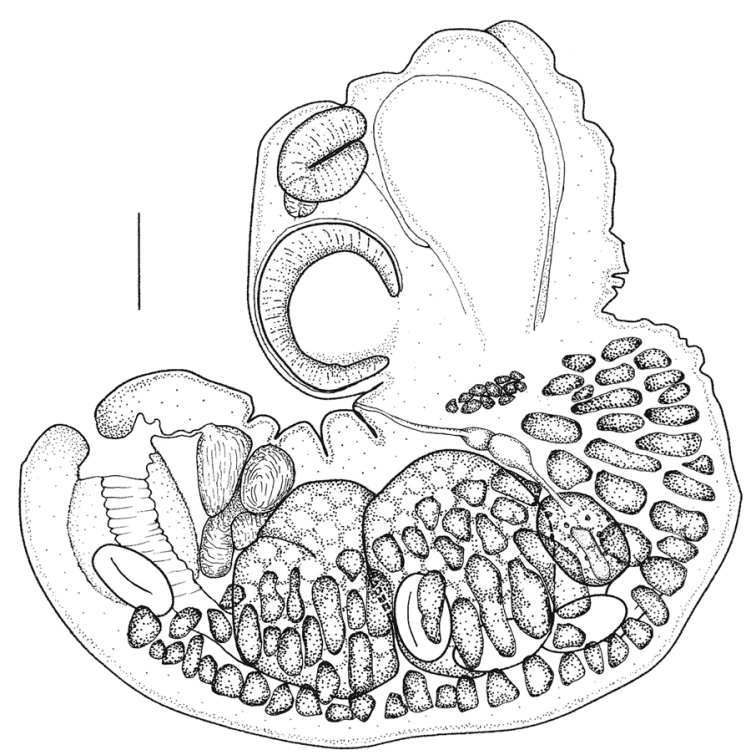

Fig. 4 Australapemon minor from crested grebe, Lake Wanaka. Scale $=100 \mu \mathrm{m}$

\section{Description}

(Based on 3 adult specimens) A small strigeid with dorsally curled body shape. Total length $1.0-1.1 \mathrm{~mm}$; maximum width at level of ventral sucker in forebody. Forebody 311-363 long, 327-421 wide. Hindbody 699-806 long, 329-393 wide at level of anterior testis. Ratio of forebody to hindbody length 1:2.0-2.3. Oral sucker 101-108 long, 80-97 wide. Pharynx round, 52 long, 51 wide. Ventral sucker 130-165 long, 110-143 wide. Ovary oval, 87-94 long, 115-128 wide; positioned at $22 \%$ length of hindbody. Testes bilobed; anterior testis positioned at 24-33\% of hindbody, 141-195 long, 217-222 wide. Posterior testis positioned at 46-57\% of hindbody, 135-141 long, 169-193 wide. Vitellaria follicular, confined to hindbody. Eggs 85-103 long, 50-54 wide. Genital cone delimited from surrounding parenchyma. Ejaculatory duct joins distal part of uterus at apex of genital cone. Hermaphroditic duct with internal rugae. Ringnapf absent.

\section{Remarks}

The small size of these specimens makes them comparable most closely to A. minor, which was described from the mallard, Anas platyrhynchos L. but which has also been reported from grebes (Sitko \& Heneberg, 2015). The measurements of our specimens fit generally within the ranges given by Yamaguti (1933) (body length $0.8-1.2 \mathrm{~mm}$, forebody length 250-460, hindbody length 540-750, forebody:hindbody ratio 1:2) although the size ranges of the oral and ventral suckers and the pharynx, overlap those given for A. minor. In addition, the eggs of our specimens are smaller than those reported for A. minor. It is possible that these constitute an unreported species of Australapatemon, but without DNA sequence support (amplification was unsuccessful), and with few specimens, it would perhaps be premature to allocate these specimens to a new species of Australapatemon. We therefore tentatively attribute them to A. minor until more specimens allow further investigation.

\section{Diplostomidae Poirier, 1886 Tylodelphys Diesing, 1850}

Type species: Diplostomum clavatum Nordmann, 1832

Tylodelphys darbyi Presswell \& Blasco-Costa, 2019 
This species was found in the upper intestine of all three grebe specimens, numbering 2, 31 and 7 respectively. Four specimens of matching morphology were also found in the white-faced heron. The species was previously described from some of the material reported herein (Presswell \& Blasco-Costa, 2020) and sequence of ITS1 was provided (KU588152). Here we provide $28 \mathrm{~S}$ and cox 1 as additional molecular markers (Table 1). This is the first report of $T$. darbyi since its description in 2020.

\section{Plagiorchiida La Rue, 1957 \\ Opisthorchioidea Looss, 1899 \\ Opisthorchiidae Looss, 1899 \\ Cryptocotyle Lühe, 1899}

Type species: Distoma concavum Creplin, 1825 by original designation; Cryptocotyle concava, Lühe, 1899

\section{Cryptocotyle micromorpha n. sp. Fig. 5, 6a-g}

Specimens of this very small trematode were found in their hundreds in all three grebe hosts, and also in the white-faced heron. In having linguiform body, tegumentary spines, ventrogenital sac with protractile bulge bearing rudimentary ventral sucker, and oblique testes they were assignable to genus Cryptocotyle Lühe, 1899 (Pearson, 2008). Comparison to described species of Cryptocotyle revealed morphological differences that indicated this was a hitherto undescribed species, and a formal description follows. Comparative morphometrics are given for C. micromorpha $\mathbf{n}$. sp. and other linguiform species (Table 4).

\section{Description}

(Based on 26 whole-mounted, gravid worms). Body linguiform 436-794 (622) long, 137-361 (237) wide; widest at level of testes. Most specimens with posterior edges curled ventrally, forming concave body shape. Body length (BL) to width ratio 1:2.0-3.0 (2.7). Tegument with scales, $2 \mu \mathrm{m}$ long, densest on forebody. Forebody scales heptafid, more posteriorly pentafid, each lobe terminating in a point (Fig. $6 \mathrm{~b}$ and c). Forebody 223-438 (310) long; forebody length 43-57 (50)\% BL. Oral sucker subterminal, 40-64 (49) long, 41-73 (55) wide. Prepharynx very short, or absent. Pharynx spherical, 22-44 (30) long, 22-45

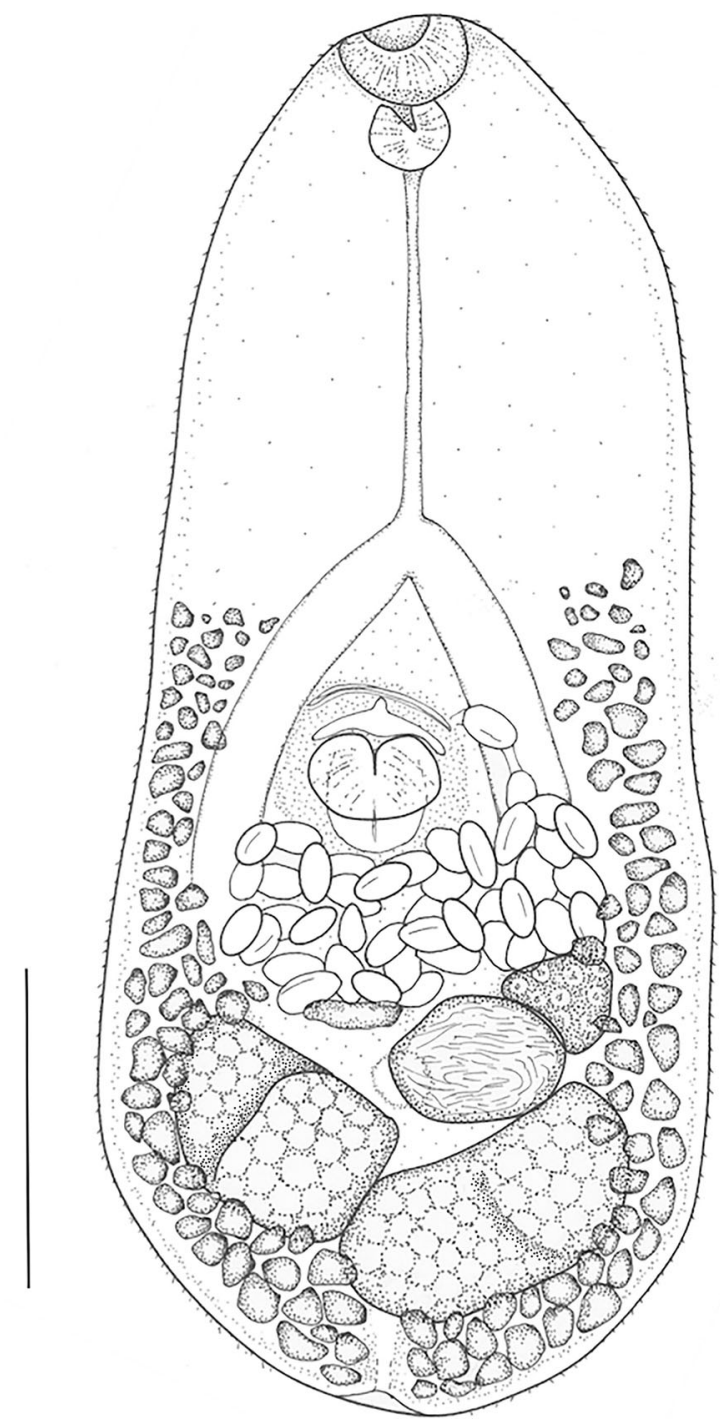

Fig. 5 Cryptocotyle micromorpha n. sp. from crested grebe, Lake Wanaka. Scale $=100 \mu \mathrm{m}$

(32) wide. Oesophagus 91-139 (111) long. Intestinal bifurcation approximately half way between oral sucker and ventral sucker; caeca terminate close to posterior end of body. Ventrogenital sac in median third of body, 27-52 (44) long, 34-52 (44) wide; surrounded by glandular cells, containing rudimentary ventral sucker on protractile bulge of posterior sac wall, and anterior pocket. Bulge of ventrogenital sac usually protruding through sac opening to greater or lesser degree (Fig. 6e, f, g). Prominent transverse band of muscle fibres slightly anterior to ventrogenital sac opening. Margins of ventral sucker not usually 

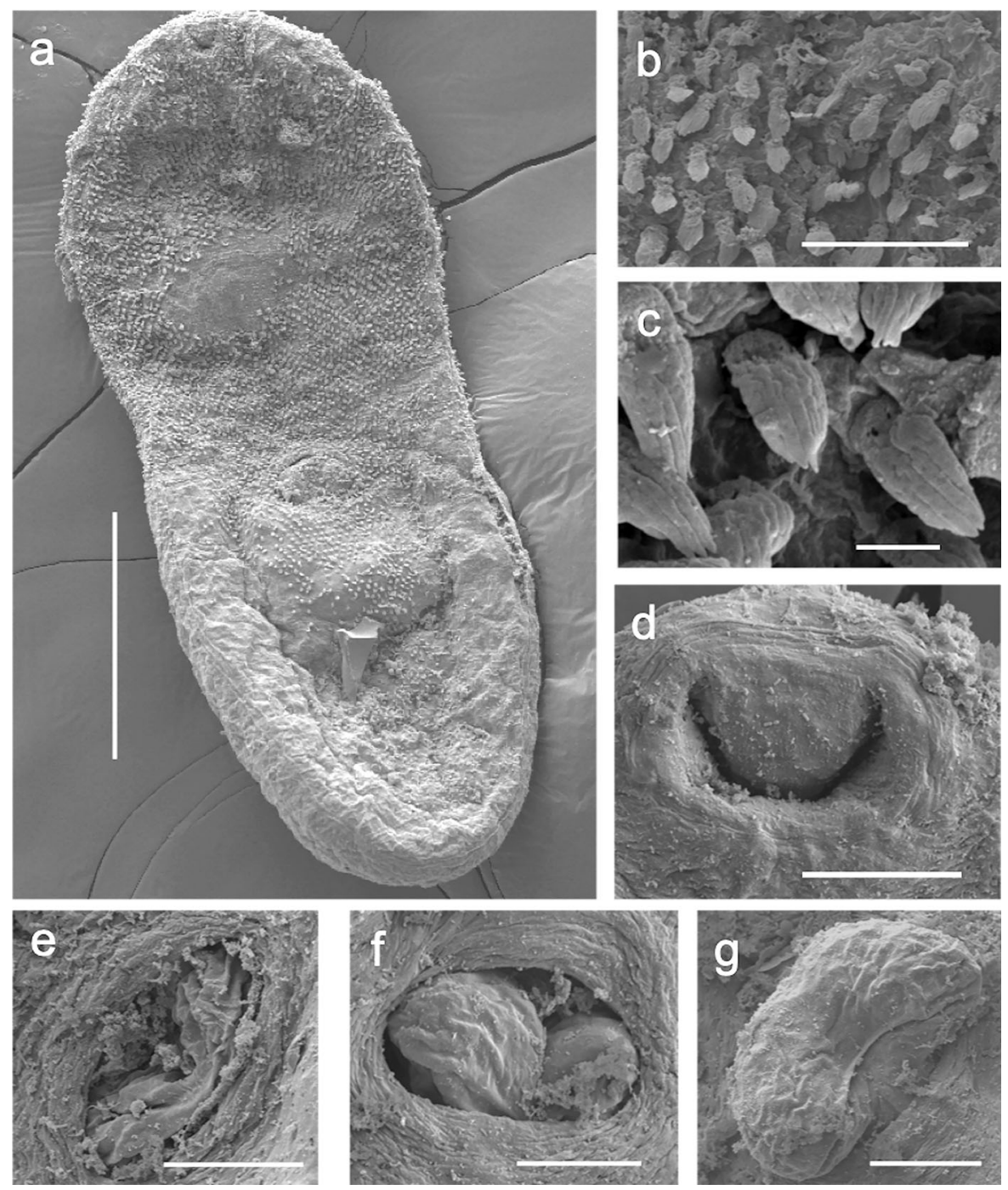

Fig. 6 Scanning electron micrographs of trematode, Crytocotyle micromorpha $\mathbf{n}$. sp., from crested grebe, Lake Wanaka. (a) whole worm, ventral view, (b) anteroventral tegumentary scales, (c) close-up of posteroventral tegumentary scales showing 5 longitudinal lobes, (d) close up of oral sucker, (e) ventral sucker with sac retracted, (f) ventral sucker with protractile bulge semi-everted, (g) ventral sucker with protractile bulge fully everted. Scale $a=100 \mu \mathrm{m} ; \mathrm{b}=10 \mu \mathrm{m} ; \mathrm{c}=1 \mu \mathrm{m} ; \mathrm{d}, \mathrm{e}, \mathrm{f}, \mathrm{g}=20 \mu \mathrm{m}$

discernible. Testes in posterior third of body, bilobed, oblique, long axes at right angles to each other. Left testis usually elongate oval; 67-164 (112) long, 56-128 (81) wide. Right testis subround to irregular, 66-143 (92) long, 56-128 (81) wide. Ovary usually sinistral, with irregular margins, oval to subtriangular, anterior to testes, overlapped wholly or partly by loops of uterus; 30-67 (42) long, 36-82 (57) wide. Seminal receptacle, sinistral, anterior to testes, partly overlapping ovary. Mehlis' gland median, level with seminal receptacle. Uterus intercecal with several serpentine loops filled with up to 140 eggs in fully mature specimens, located mainly between ventrogenital sac and seminal receptacle, but with final loop anterior to ventrogenital sac; the exact path not observed but one to several eggs always found anterior to ventrogenital complex in mature worms. Vitelline follicles extend anteriorly to level midway between caecal bifurcation and ventrogenital sac, posteriorly to end of body. Eggs operculate 24-30 (28) long, 13-19 (16) wide. Excretory vesicle $\mathrm{Y}$-shaped; excretory pore at posterior end of body. 
Table 4 Measurements of Cryptocotyle species with linguiform body shape and oblique or tandem testes.

\begin{tabular}{|c|c|c|c|c|c|c|}
\hline Authority & $\begin{array}{l}\text { micromorpha } \mathbf{n} \text {. sp. } \\
\text { This study }\end{array}$ & $\begin{array}{l}\text { Casalins, } \\
\text { Arbetman, } \\
\text { Viozzi \& } \\
\text { Flores, } 2020\end{array}$ & $\begin{array}{l}\text { (Nicoll, 1907) } \\
\text { Ransom, } 1920\end{array}$ & $\begin{array}{l}\text { (Creplin } \\
1825) \\
\text { Fischoeder, } \\
1903\end{array}$ & $\begin{array}{l}\text { McIntosh, } \\
1953\end{array}$ & $\begin{array}{l}\text { Cryptocotyle } \\
\text { sp. } \\
\text { Zdzitowiecki } \\
\text { et al. } 1989\end{array}$ \\
\hline $\begin{array}{l}\text { Hosts [Type } \\
\text { host BOLD] }\end{array}$ & $\begin{array}{l}\text { Podiceps cristatus } \\
\text { australis, Egretta } \\
\text { Novaehollandiae, Larus } \\
\text { dominicanus }\end{array}$ & $\begin{array}{l}\text { Larus } \\
\text { dominicanus }\end{array}$ & $\begin{array}{l}\text { Tringa totanus, } \\
\text { gulls, terns, other } \\
\text { birds and } \\
\text { mammals }\end{array}$ & $\begin{array}{l}\text { Larus } \\
\text { marinus, } L . \\
\text { argentatus, } L . \\
\text { fuscus }\end{array}$ & $\begin{array}{l}\text { Pteronura } \\
\text { brasiliensis, } \\
\text { Lutra } \\
\text { longicaudis }\end{array}$ & $\begin{array}{l}\text { Larus } \\
\text { dominicanus }\end{array}$ \\
\hline Habitat & Freshwater & $\begin{array}{l}\text { Marine or } \\
\text { freshwater }\end{array}$ & Marine & Marine & Freshwater & Marine \\
\hline locality & New Zealand & Argentina & $\begin{array}{l}\text { Europe , N. } \\
\text { America, Asia }\end{array}$ & $\begin{array}{l}\text { Europe , N. } \\
\text { America, } \\
\text { Asia }\end{array}$ & $\begin{array}{l}\text { South } \\
\text { America }\end{array}$ & Antarctica \\
\hline $\begin{array}{l}\text { Length }(\mathrm{mm}) \\
\quad(\mathrm{BL})\end{array}$ & $0.436-0.794$ & $1.296-1.939$ & $0.870-1300$ & $1.5-1.7$ & 3.1 & $0.720-0.900$ \\
\hline $\begin{array}{l}\text { Widest width } \\
\text { (BW) }\end{array}$ & $137-361$ & $490-672$ & $20 \% \mathrm{BL}$ & $400-900$ & 790 & $370-450$ \\
\hline $\mathrm{BL} / \mathrm{BW}$ & $2.06-3.05$ & $2.7-2.9$ & $2.5^{*}$ & $2.8^{*}$ & $3.9^{*}$ & $1.9-2.0^{*}$ \\
\hline $\begin{array}{l}\text { BL/Forebody } \\
\text { length }\end{array}$ & $1.8-2.3$ & $2.07 *$ & $2.18 *$ & 2.8 & $1.6^{*}$ & $1.9^{*}$ \\
\hline $\begin{array}{l}\text { Oral sucker } \\
\text { length }\end{array}$ & $40-64$ & $50-106$ & 45 & 80 & 70 & $64-65$ \\
\hline $\begin{array}{l}\text { Oral sucker } \\
\text { width }\end{array}$ & $41-73$ & $59-87$ & 45 & - & 80 & $72-74$ \\
\hline $\begin{array}{c}\text { Pharynx } \\
\text { length }\end{array}$ & $22-44$ & $42-61$ & 38 & 60 & 80 & $54-61$ \\
\hline Pharynx width & $22-45$ & $28-56$ & 18 & 30 & 65 & $35-46$ \\
\hline Oesophagus & $91-139$ & $56-154$ & 100 & $28-32$ & 175 & 57 \\
\hline $\begin{array}{l}\text { Ventrogenital } \\
\text { sac length }\end{array}$ & $27-52$ & - & 55 & - & 117 & 110 \\
\hline $\begin{array}{l}\text { Ventrogenital } \\
\text { sac width }\end{array}$ & $34-52$ & - & - & - & 100 & 100 \\
\hline Ovary shape & $\begin{array}{l}\text { irregular, reniform, } \\
\text { subtrianglular }\end{array}$ & irregular & oval lobed right & trilobed & irregular & lobed \\
\hline Ovary length & $30-67$ & $86-168$ & - & 80 & 250 & $70-90$ \\
\hline Ovary width & $36-82$ & $98-375$ & - & 180 & 340 & 140 \\
\hline $\begin{array}{l}\text { Testes } \\
\text { placement }\end{array}$ & $\begin{array}{l}\text { Irregular oval, bilobed, } \\
\text { oblique. }\end{array}$ & Oblique & $\begin{array}{l}\text { Irregular oval } \\
\text { indented on } \\
\text { posterior border, } \\
\text { oblique }\end{array}$ & Oblique & $\begin{array}{l}\text { Irregular } \\
\text { lobed, } \\
\text { tandem, } \\
\text { equal }\end{array}$ & Oblique \\
\hline $\begin{array}{l}\text { Left testis } \\
\text { length }\end{array}$ & $67-164$ & $62-252$ & - & 250 & 250 & $140-150$ \\
\hline $\begin{array}{l}\text { Left testis } \\
\text { width }\end{array}$ & $57-116$ & $154-288$ & - & 130 & 300 & $130-140$ \\
\hline $\begin{array}{l}\text { Rght testis } \\
\text { length }\end{array}$ & $66-143$ & - & - & - & - & $170-190$ \\
\hline $\begin{array}{l}\text { Right testis } \\
\text { width }\end{array}$ & 56-128 & - & - & - & - & $100-120$ \\
\hline
\end{tabular}


Table 4 continued

\begin{tabular}{|c|c|c|c|c|c|c|}
\hline & micromorpha $\mathbf{n}$. sp. & dominicana & jejuna & lingua ${ }^{a}$ & thapari & Cryptocotyle \\
\hline Authority & This study & $\begin{array}{l}\text { Casalins, } \\
\text { Arbetman, } \\
\text { Viozzi \& } \\
\text { Flores, 2020 }\end{array}$ & $\begin{array}{l}\text { (Nicoll, 1907) } \\
\text { Ransom, } 1920\end{array}$ & $\begin{array}{l}\text { (Creplin } \\
1825) \\
\text { Fischoeder, } \\
1903\end{array}$ & $\begin{array}{l}\text { McIntosh, } \\
1953\end{array}$ & $\begin{array}{l}\text { Zdzitowiecki } \\
\text { et al. } 1989\end{array}$ \\
\hline $\begin{array}{l}\text { Hosts [Type } \\
\text { host BOLD] }\end{array}$ & $\begin{array}{l}\text { Podiceps cristatus } \\
\text { australis, Egretta } \\
\text { Novaehollandiae, Larus } \\
\text { dominicanus }\end{array}$ & $\begin{array}{l}\text { Larus } \\
\text { dominicanus }\end{array}$ & $\begin{array}{l}\text { Tringa totanus, } \\
\text { gulls, terns, other } \\
\text { birds and } \\
\text { mammals }\end{array}$ & $\begin{array}{l}\text { Larus } \\
\text { marinus, } L . \\
\text { argentatus, } L . \\
\text { fuscus }\end{array}$ & $\begin{array}{l}\text { Pteronura } \\
\text { brasiliensis, } \\
\text { Lutra } \\
\text { longicaudis }\end{array}$ & $\begin{array}{l}\text { Larus } \\
\text { dominicanus }\end{array}$ \\
\hline Habitat & Freshwater & $\begin{array}{l}\text { Marine or } \\
\text { freshwater }\end{array}$ & Marine & Marine & Freshwater & Marine \\
\hline locality & New Zealand & Argentina & $\begin{array}{l}\text { Europe , N. } \\
\text { America, Asia }\end{array}$ & $\begin{array}{l}\text { Europe , N. } \\
\text { America, } \\
\text { Asia }\end{array}$ & $\begin{array}{l}\text { South } \\
\text { America }\end{array}$ & Antarctica \\
\hline Vitellaria & $\begin{array}{l}\text { Halfway between VS \& } \\
\text { bifurcation. Extracaecal }\end{array}$ & $\begin{array}{l}\text { Halfway } \\
\text { between VS } \\
\text { and bifurc. } \\
\text { Intercaecal }\end{array}$ & $\begin{array}{l}\text { Level with VS. } \\
\text { Intracaecal }\end{array}$ & & $\begin{array}{l}\text { Between VS } \\
\text { and } \\
\text { bifurcation. } \\
\text { Intracaecal }\end{array}$ & $\begin{array}{l}\text { Level of } \\
\text { bifurcation }\end{array}$ \\
\hline Egg length & $24-30$ & $25-33$ & $31-36$ & 48 & 34 & $29-34$ \\
\hline Egg width & $13-19$ & $14-19$ & $16-19$ & 22 & 18 & $12-19$ \\
\hline
\end{tabular}

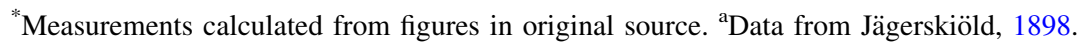

\section{Taxonomic summary}

Type Host. Australasian crested grebe, Podiceps cristatus australis Gould (Aves, Podicipediformes, Podicipedidae).

Other hosts. White-faced heron, Egretta novaehollandiae (Latham) (Aves, Pelicaniformes, Ardeidae); Southern black-backed gull, Larus dominicanus Lichtenstein (Aves, Charadriiformes, Laridae).

Site in host. Intestine

Type locality. Roy's Bay, Lake Wanaka, Otago (4441'22”S, 16907'49”E)

Prevalence and intensity of infection: approximately 600, 200 and $>1000$ were found in each of three grebes Specimens deposited. Te Papa Museum, Wellington, New Zealand: Holotype (W.003609), Paratypes (W.003610-12).

Genbank Accession number. OL470523 (parital 28S gene), OL504983 (cox1 gene)

Zoobank Registration. urn:lsid:zoobank.org:act: 57B48D73-8142-40F3-B3E5-50FD48D6DB11

Etymology. The species name micromorpha, a noun in apposition derived from the Greek "mikros" (= small) and "morphi" (= shape), refers to the small body size of this species.
Partial sequences of $28 \mathrm{~S}$ and $\operatorname{cox} 1$ were obtained for specimens from two grebes (Table 1), both of which were identical in the two host birds. In BLASTn searches, the $28 \mathrm{~S}$ showed greatest similarity with Cryptocotyle lingua (96.72\% over 609bp), and the cox 1 sequence was closest to C. lingua (81.95-83.96\% similarity) and C. concava (80.54-81.95\% similarity).

\section{Remarks}

The genus Cryptocotyle contains 13 species (Sokolov et al., 2016; Tatanova \& Besprozvannykh 2019; Kamiya \& Ohbayashi, 1975; Casalins et al., 2020), of which 9 have body shapes that are distinctly pentagonal or ovoid, with testes opposite and vitellaria extending anteriorly to the level of the caecal bifurcation: C. badamshini (Kurochkin, 1959) Yamaguti, 1971, C. concava (Creplin, 1825) Lühe, 1899, C. cryptocotyloides (Issaitschikov, 1923) Witenberg, 1929, C. delamurei (Yurakhno, 1987), C. gyrinicola (Dollfus \& Timon-David, 1960) Sokolov, Protasova, Lebedeva, Gorlacheva \& Gorlachev 2016, C. lata Tatanova \& Besprozvannykh, 2019, C. misgurni (Ohyama, Okino \& Ushirogawa, 2001) Sokolov, Protasova, Lebedeva, Gorlacheva \& Gorlachev, 2016, C. quinqueangularis (Skrjabin, 1923) 


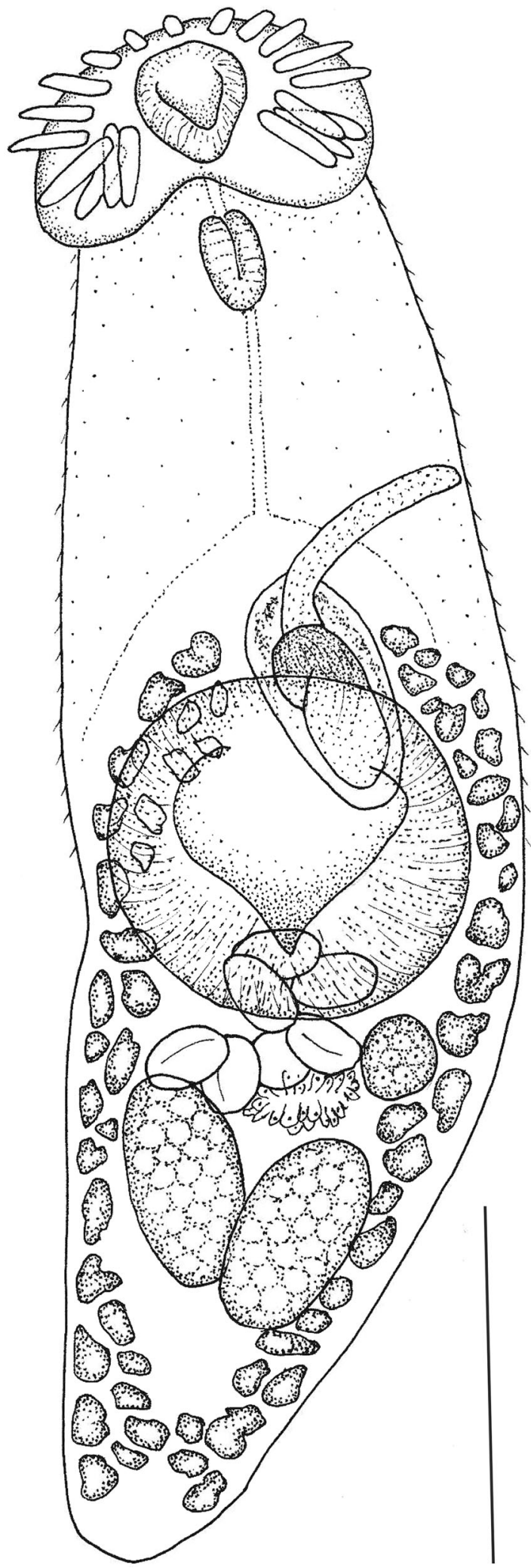

४Fig. 7 Neopetasiger neocomensis from crested grebe, Lake Wanaka, New Zealand. Scale $=300 \mu \mathrm{m}$

Witenberg, 1929, and C. yamashitai (Kamiya \& Ohbayashi, 1975).

The remaining four species are linguiform in shape, as are the specimens reported herein. Cryptocotyle micromorpha n. sp. may be distinguished from $C$. dominicana Casalins, Arbetmam, Viozzi \& Flores, 2020, C. jejuna (Nicoll, 1907) Ransom, 1920, C. lingua (Creplin, 1825) Lühe, 1899 and. C. thapari McIntosh, 1953 by its smaller body size and the distribution of the vitellaria which do not extend intercaecally. Additionally, in Cryptocotyle micromorpha n. sp. the metraterm loops around, and anterior to, the ventrogenital sac, a condition that does not appear to occur in any of these species.

\section{Echinostomatoidea Looss, 1902 \\ Echinostomatidae Looss, 1902 \\ Neopetasiger Baschkirova, 1941}

Type species: Neopetasiger skrjabini Baschkirova, 1941

Neopetasiger neocomensis Fuhrmann, 1927 Fig. 7

Synonyms: Echinostomum pungens Linstow, 1894 sensu Odhner (1910); Petasiger longicirratus Ku, 1938; P. skrjabini Bashkirova, 1941; Petasiger megacanthus (Kotlán, 1922) sensu Prudhoe (1945); Echinostoma megacantha (Kotlán, 1922) sensu Issaitschikov (1927); P. nitidus sensu Chen et al. (1985)

A total of 285 specimens of this small echinostomid trematode were found in the upper intestine of all three grebe hosts (145, 100 and 40 respectively), and in the white-faced heron. In having a fusiform body with a constriction in the 'neck' region, tegument armed with small dense scales in forebody, 19 collar spines, subspherical oral sucker, pharynx smaller than oral sucker, broadly oval cirrus sac extending to middle of ventral sucker, long tubular unarmed cirrus, post equatorial ovary and in its podicipedid host, these specimens conformed to the diagnosis of genus Neopetasiger Bashkirova, 1941 as emended by Tkach et al. (2016). Comparing the morphometrics and 
description to the 14 species listed as valid in Tkach et al. (2016) these specimens are identifiable as $N$. neocomensis, originally described from the same host, Podiceps cristatus, in Switzerland (Fuhrmann, 1927). We include brief measurements below.

\section{Description}

(Based on 11 ovigerous specimens). Body elongate, spinose to level of anterior testis ventrally, 1.18-1.46 mm long, 371-414 wide; maximum width at level of ventral sucker. Oral sucker subterminal, 73-108 , 71-104 wide. Collar with 19 spines, two groups of 4 angle spines (82-123 long), longer than lateral (52-83 long) and dorsal (65-97). Prepharynx 45-81 long. Pharynx 61-89 long, 50-63 wide. Oesophagus 124-252 long. Forebody $37-44 \%$ body length. Ventral sucker 220-312 long, 228-330 wide. Ratio of oral sucker width to ventral sucker width 1:0.29-0.41. Testes oblique, elongate oval; anterior testis 128-210 long, 78-127 wide, posterior testis 137-176 long, 85-119 wide. Cirrus sac muscular, elongate oval, 170-215 long, 72-110 wide, between intestinal bifurcation and mid-level of ventral sucker, containing bipartite seminal vesicle, and long, tubular unarmed cirrus, up to 458 long and 30 wide. Genital pore median, at level of intestinal bifurcation. Ovary oval, sinistral, pretesticular; 57-96 wide. Vitellarium in 2 lateral fields of relatively small follicles, extends from near level of genital pore to near posterior extremity; fields converge in posttesticular region.Uterus short, only 1-2 loops between anterior testis, ovary and ventral sucker. Eggs 76-83 long, 44-60 wide.

We obtained a partial $28 \mathrm{~S}$ sequence for two specimens which were identical. In a BLASTn search these found $100 \%$ similarity (560bp) with Petasiger sp.1 of Selbach et al. (2014) from first intermediate hosts, Gyraulus albus and Planorbis planorbis in Czech Republic and Germany (KM191800 and KM191799).

\section{Remarks}

In their paper, Selbach et al. (2014) found four different cercarial or metacercarial genotypes of Petasiger spp., and documented morphological differences between them. The authors suggested that two of their cercarial stages could belong to Petasiger pungens (Linstow, 1893) and P. neocomensis (both species now in Neopetasiger - see Tkach et al. 2016). In addition to this genetic match, the morphological features of our specimens, and the fact that $N$. neocomensis was described from Podiceps cristatus and is the only species of Neopetasiger recorded from this host, we believe we can confirm that Petasiger sp. 1 of Selbach et al. (2014) is, indeed, N. neocomensis.

\section{Orthographic note}

Storer (2000) pointed out that the name Petasiger is masculine and proposed Yamaguti's (1958) use of "neocomensis" as opposed to "neocomense" as correct. We concur with this usage and add that Neopetasiger pseudoneocomense Bravo-Hollis, 1971 should also be changed to N. pseudoneocomensis, under article 34.2 of the International Code of Zoological Nomenclature.

\section{CESTODA Rudolphi, 1808 \\ Cyclophyllidea van Beneden in Braun, 1900 Hymenolepididae Ariola, 1899 \\ Confluaria Ablasov, 1953}

Type species: Confluaria spasskii Ablasov, 1953 Confluaria pseudofurcifera Vasileva, Georgiev \& Genov, 2000. Fig. 8

Synonyms: Hymenolepis furcigera (Krabbe, 1869) sensu Joyeux \& Baer (1950), Jarecka (1958) and Korpaczewska (1960); Confluaria furcifera (Krabbe, 1869) sensu Galkin (1986) and Rysavy \& Sitko (1995)

Specimens of this delicate cestode were found in all three grebe hosts (1 scolex; 4 scoleces and many pieces; 40 scoleces and many pieces). In having 10 rostellar hooks, aploparaksoid with large epiphyseal thickenings, invaginable rostellum, four unarmed suckers, and craspedote proglottides with unilateral genital pores these specimens could be assigned to the genus Confluaria Ablasov, 1953. Of the eight species currently recognised (Vasileva et al., 1999b, 2000, 2001, 2008; Bondarenko \& Kontrimavichus, 2018), the hook size, and the shape and extent of the epiphyseal thickening unequivocally match those of $C$. pseudofurcifera, which was described from Podiceps cristatus from Bulgaria. We include a brief description below.

\section{Description}




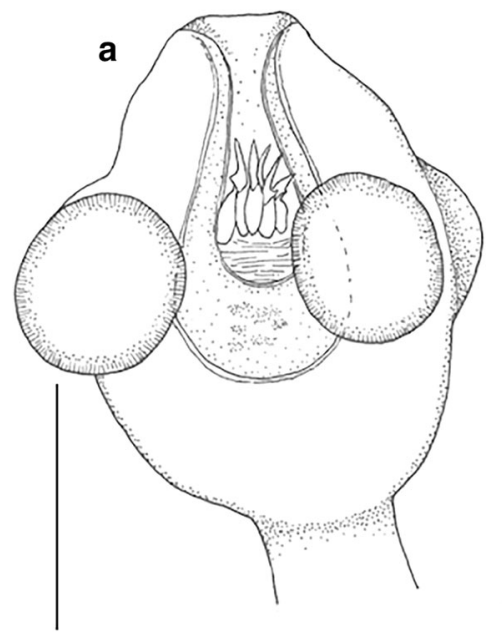

b

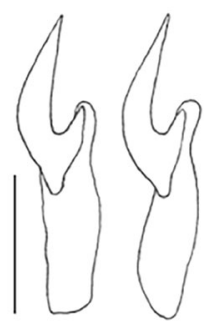

Fig. 8 Cestode Confluaria pseudofurcifera from crested grebe, Lake Wanaka, New Zealand. (a) scolex, (b) 2 rostellar hooks. Scale $\mathrm{a}=100 \mu \mathrm{m} ; \mathrm{b}=20 \mu \mathrm{m}$

(Based on 1 entire and 12 part specimens). Strobila maximum length 55mm, maximum width 784 . Scolex 193-278 long, 150-181 wide, widest at suckers. Neck very long. Suckers round, unarmed, with well-developed musculature; 66-77 long, 60-72 wide. Rostellum with apical enlargement and muscular walls; width at top of rostellum 66-76. Rostellar sheath with weaklydeveloped musculature, length exceeds posterior margins of suckers. Rostellum with single crown of 10 hooks, each with aploparaksoid refractive particle with long straight blade, short straight handle and slightly larger guard; 19-21 long. Hooks with large epiphyseal thickening encompassing both handle and guard; hook length including epiphyseal thickening 28-37. Proglottides craspedote, much wider than long. Genital pores unilateral, central at edge of proglottis. Genital atrium deep, cylindrical. Cirrus with short, conical basal enlargement armed with rosethorn spines, seminal receptable elongate.

A partial $28 \mathrm{~S}$ gene was sequenced for four individuals which were identical, and gave a BLAST result of assorted Hymenolepidids with a maximum similarity of $93.60 \%$. There are currently no sequences of Confluaria spp. on GenBank, so no relationships can be inferred at this time.

\section{Remarks}

A number of works by Vasileva et al. (1999a, b, 2000, 2001, 2008) have reviewed this genus and present excellent descriptions and a key (Vasileva et al., 2000) from which the New Zealand specimens can be identified as $C$. pseudofurcifera. Only in two species does the epiphyseal thickening attach to both the handle and the guard of the rostellar hook; C. pseudofurcifera and C. podicipina (Szymanski, 1905). The epiphyseal thickening of $C$. podicipina is conspicuously more massive. Although no specimen was found with everted cirri, the base of the inverted cirrus was undoubtedly like that of $C$. pseudofurcifera with a short, thick enlargement armed with rosethorn spines.

\section{Discussion}

We found a total of 7 helminth species infecting three crested grebes in Otago, New Zealand: 2 nematodes (Contracaecum ovale and Baruscapillaria kamanae $\mathbf{n}$. sp.), 4 trematodes (Australapatemon minor, Cryptocotyle micromorpha n. sp., Tylodelphys darbyi and Neopetasiger neocomensis), and 1 cestode (Confluaria pseudofurcifera). Previous to this study there were no records of gastrointestinal cestodes or trematodes from the crested grebe in New Zealand. Apart from the two new species, and $T$. darybi, all the species reported herein have been recorded from Podiceps cristatus in other parts of the world, but all of them are new records for New Zealand. Below we discuss the taxonomic histories, known biology and life cycles of the parasites, and host specificity in the crested grebe.

Until now, no Contracaecum species has been reported from freshwater birds in New Zealand (McKenna, 2010). However, C. podicipitis (now $C$. ovale - see below) was originally described from Podiceps cristatus australis from Australia (Johnston $\&$ Mawson 1949). In addition to the specimens from the grebe, we also found over 100 specimens of the same species (confirmed by DNA identity) in the white-faced heron from Lake Wanaka. Although there are over 100 species in the genus Contracaecum (Shamsi 2019), most are found in marine environments, and there are few species found in Podicipediformes. Based on the literature, all those species reported from grebes have a distinctive head morphology, in that the interlabia are greatly reduced in size, usually reaching to about $1 / 3$ the height of the lips, and lack any bifurcation. In addition, these species lack the conspicuous annulations of the 
cephalic collar, interrupted by a lateral groove seen in other, mainly marine, Contracaecum species. We therefore compared our specimens to only those found with these features from grebes, of which there are six nominal species: C. nehli Karokhin, 1949; C. ovale (Linstow, 1907); C. podicipitis Johnston \& Mawson, 1949; C. praestriatum Monnig, 1923; C. ruficolle Vuylsteke, 1953 and C. spasskii Mozgovoi, 1959. The validity of all of these species has been called into question by various authors. Indeed, Macko (1961) and Hartwich (1964) regarded C. nehli, C. spasskii and C. ruficolle as synonyms of $C$. ovale and Baruš \& Zajíček (1967) included C. podicipitis in its synonyms. The original description of $C$. ovale (Linstow 1907) was short on detail, and various descriptions of the species have been published since (i.e. Cram, 1927; Mozgovoi, 1953; Macko, 1961; Hartwich, 1964; Galeano \& Tanzola, 2012). Those reports that gave morphometrics have greatly increased the range of measurements and interspecific variability in all features, notably the size of spicules and number of male papillae. This being the case then it seems sensible to accept the synonymisations of $C$. nehli, $C$. podicipitis, C. ruficolle and C. spasskii, which fall within the ranges given by the above authors. Contracaecum praestriatum, however, does appear to have some distinctive characters, not least the presence of a gubernaculum and thick lips with rounded outline, and an abrupt change in the nature of the cuticular striations at one third of the body length (Monnig, 1923). For the present the most parsimonious approach to the 'grebe' species is to follow previous workers (Macko, 1961; Hartwich, 1964; Baruš \& Zajíček, 1967; Baruš et al., 1978) and include them all (except for $C$. praestriatum) in $C$. ovale, until such time as genetic data are available from each of the putative species to elucidate their distinctiveness or lack thereof. Further sequences from all Contracaecum from grebes, or other freshwater fish eating birds, should help elucidate the taxonomy and evolutionary history of this species group.

Apart from the unnamed species mentioned previously (Presswell \& Bennett, 2021) the only records of Baruscapillaria species (reported as Capillaria) from New Zealand, are from terrestrial birds: B. emberizae (Yamaguti, 1941) in a yellowhammer Emberiza citrinella L. and B. obsignata (Madsen, 1945) in domestic fowl Gallus domesticus L. and rock pigeon Columba livia (Gmelin) (McKenna, 2010). What little is known of the life cycle of Baruscapillaria spp. suggests that their life histories are variable. Baruscapillaria obsignata has been shown to have a direct life cycle with no intermediate hosts (Moravec et al., 1987), but those species infecting grebes are believed to use oligochaetes as intermediate hosts (Storer, 2000). Although three species of Baruscapillaria are hosted in Podicipediformes (B. mergi, B. podicipitis and $B$. ryjikovi), only $B$. podicipitis is recorded from Podiceps cristatus. However, B. podicipitis is not host-specific, also occurring in other grebes and Anseriformes, Lariformes (Baruš et al., 1978) and Pelicaniformes (this study).

One other species of Australapatemon has been recorded from New Zealand; Australapatemon niewiadomski Blasco-Costa, Poulin \& Presswell, 2016 from the mallard duck. This species is larger in all metrics than the specimens found in the grebes. The specimens of $A$. minor were found in the upper intestine. In the gizzard of the second two grebes, and in the heron, were found thousands of metacercarial cysts of the strigeid type, along with a few juvenile excysted individuals. It was clear that, despite the huge numbers of strigeid cysts found in the gizzards of these birds, only these three parasite individuals had successfully passed through into the intestine and matured. However, several questions remain concerning this phenomenon: 1) if this species is able to mature in the grebe intestine as evidenced by the three mature specimens, why did we not see 1000 s of mature specimens in the intestine?,2) could the three mature specimens belong to a different strigeid species that is able to mature in the grebe, whereas the thousands in the gizzard were able only to excyst before expiring? (unfortunately, DNA amplification did not work for the strigeid cysts, nor the three adults, so we are unable to say whether or not they are the same species), 3) Australapatemon spp. are known to infect leeches as their second intermediate hosts. Although it is quite feasible that grebes would eat the occasional leech, it seems unlikely that they would ingest enough to accumulate the thousands of metacercariae in the gizzard, especially considering that grebes void at least part of their gizzard contents daily as pellets (Jehl, 2017). This leaves the likelihood that the cysts belong to a species of Apatemon, (possibly Apatemon sp., "jamiesoni" that occurs in large numbers in bullies Gobiomorphus cotinianus MacDowall). This species, yet to be formally named, has been found in a 
mallard, and a black-backed gull Larus dominicanus Lichtenstein (Presswell unpubs. data). On the assumption that the cysts in the gizzard are not $A u$. minor, we have not included these cysts as part of the grebe parasite fauna, as it seems they are unable to persist in the grebe. There is no doubt that there are more strigeid species yet to be found in New Zealand (Blasco-Costa et al., 2016), so this is a puzzle that will have to await more evidence.

As well as the three grebe specimens, Tylodelphys darbyi was also found in a single white-faced heron from Lake Wanaka. The second intermediate host of this trematode species is the bully (Gobiomorphus cotidianus), in which the metacercariae inhabit the eyes. The initial report of this larval stage was from Lake Hayes, in Otago (Blasco-Costa et al., 2017). However, the species has since been found in bullies in Lakes Wanaka and Hawea (both lakes with grebe populations) and Lake Heron (Ashburton Lakes) (also with a healthy grebe population), considerably further north (Ruehle et al. in press). Despite extensive searching among the gastropod fauna of Lakes Wanaka and Hawea, the first intermediate host of this diplostomid has not yet been found.

Cryptocotyle micromorpha $\mathbf{n}$. sp. is the first named species of opisthorchiid reported from a New Zealand bird; the only previous report was an unnamed species of Metorchis in a "wild duck" (Rind, 1974). The genus Cryptocotyle has traditionally been considered a member of family Heterophyidae (Pearson, 2008), but recent genetic studies convincingly place the genus into family Opisthorchiidae (Thaenkham et al., 2011, 2012; Tatonova and Besprozvannykh, 2019; Sokolov et al., 2021), and Sokolov et al. (2021) provided emended diagnoses of the family and its superfamilies to take these changes into account. However, genetic relationships within the genus Cryptocotyle are still relatively unknown and a larger range of taxa will be required to elucidate the interrelationships of the species, including our newly generated sequences. Caution is required when referring to records of $C$. lingua in the literature. Creplin's (1825) description included no measurements, except for body length, and no illustrations, so identification of the species in the literature has been speculative, leading to a range of measurements that surely exceed the original species. Therefore, it is a matter of conjecture which source is used as a substitute for comparison. In this case we have used data from
Jägerskiöld (1898) who confirmed identity of his specimens directly with those of Creplin. Specimens of C. micromorpha n. sp. have also been found by the authors in Southern black-backed gulls (Larus dominicanus), confirmed by DNA sequence identity. Morphologically comparable specimens were found too in the white-faced heron (Egretta novaehollandiae) from the same locality as the grebes. Cryptocotyle species are found in both freshwater and marine ecosystems, and gulls (Laridae) in particular are regular definitive hosts. In New Zealand, black-backed gulls (known as Kelp gulls elsewhere in the southern hemisphere) occur both at the coast and inland on freshwater lakes and rivers. One of the black-backed gulls dissected was infected only with parasites associated with freshwater, including Cryptocotyle micromorpha $\mathbf{n}$. sp.

We present the first record in New Zealand of species of either Neopetasiger or its synonym in part, Petasiger Dietz, 1909. Neopetasiger was elevated to generic rank by Tkach et al. (2016) to include those species of Petasiger with 19 collar spines, predominantly parasitising grebes. The known distribution of Neopetasiger neocomensis includes much of central and Eastern Europe, as well as China. The history of the species includes many instances of misidentification and confusion with other species, described in detail in the revision of genus Petasiger, by Faltýnková et al. (2008). Their thorough and detailed study included measurements of new specimens from various different geographical and host sources, and measurements of our specimens fit convincingly within their given ranges for the species. Specimens of this species were also found in the white-faced heron from the same locality as the grebes, which constitute the first record of this species in a member of the Ardeidae.

We also present the first record in New Zealand of any species of Confluaria, a cestode genus that infects podicipediforms almost exclusively. In terms of numbers, cestodes constitute the dominant group in the helminth communities from grebes (Storer, 2000). Sitko and Heneberg (2015) found Confluaria sp. to be the most prevalent species of helminth in $P$. cristatus ( $80 \%$ prevalence). Specimens were found in all three of our birds, so the life cycle of this cestode obviously facilitates high prevalence, although the intermediate hosts are not known. Other species of Confluaria are reported to use cladocerans as intermediate hosts, 
although Storer (2000) suggests that it seems likely that fishes may act as paratenic or second intermediate hosts. Vasileva et al. (2000) examined specimens from several different collections and concluded that $C$. pseudofurcifera was exclusive to $P$. cristatus as they found no specimens in other grebe species.

All of the helminth parasites reported here were from the gastrointestinal tract. However, because of the rarity of dead grebe specimens, we took the opportunity to check the nasal passages of the last specimen for the possible presence of nasal schistosomes (Trichobilharzia spp.), the cause of swimmer's itch, which are found as larval stages in Lake Wanaka, and in the nasal passages of New Zealand scaup Aythya novaeseelandiae (Norm Davis pers. comm.). The livers were also examined for this worm and any other parasites, as well as other internal organs and the eyes. No parasites were found in any of these organs in the bird that we examined.

According to Storer (2000) many helminth species are found largely or exclusively in podicipedforms, but few, if any, are known to be specific to any one species of grebe. In the northern hemisphere part of the crested grebe's range 25 digenean species (22\% of all those reported from grebes) are known only from the grebe type-host, but this figure is probably highly influenced by imprecise taxonomy and identification, rather than reflecting a true estimate of host-parasite specificity. In terms of cestodes, which show the greatest degree of specialisation to podicipediform hosts, one family, the Amabiliidae, are grebe specialists, and 15 Hymenolepididae genera are also known only from grebe hosts, with 2 species known only from their grebe type-host (Storer, 2000). Nematodes show little specificity with just 6 species recorded solely from grebes of which 2 are only known from their type-host. Storer (2000) concludes that there is no evidence for a strong pattern of specificity to single definitive host species, and that those that are reported from single grebe species more likely reflect insufficient sampling effort or geographic isolation. As several of the species found in the New Zealand grebes are the same as those found in Podiceps cristatus elsewhere in the world, it would seem that the NZ population has retained much of its worm fauna in its colonisation of Australasia. There are no other sympatric grebe species with which to share its parasites (the dabchick Poliocephalus rufopectus (Gray) and
Australasian little grebe Tachybaptus novaehollandiae (Stephens) do not occur in the South Island), but we do find parallel infections (five out of seven helminth species) in the white-faced heron, which lives alongside the crested grebes and has a very similar diet.

Previous studies of parasite assemblages within Podiceps cristatus have found a more diverse helminth fauna. For instance, Sitko and Heneberg (2015) found 28 species in their birds $(n=438)$ from the Czech Republic. That we found only 7 species in our three birds no doubt reflects the huge difference in host sample sizes, but the lack of diversity in New Zealand may be real, and a consequence of the geographical remoteness of New Zealand and limited diversity of intermediate hosts to perpetuate infections. As the species dispersed to Australasia via the Pacific, Australia and thence to New Zealand, perhaps their parasite diversity was filtered out by an ever decreasing availability of intermediate hosts. Once in New Zealand, there were no other grebes from which to acquire more of the relatively specialist groups of parasites (Storer, 2000) that infect the podicipediforms. Recording helminth diversity is important in that it provides information regarding host health, diet, behaviour and ecology, and ecosystem health as a whole. This article provides a baseline for future research on the helminth diversity of an ecologically important bird species of Threatened status.

Funding Open Access funding enabled and organized by CAUL and its Member Institutions.

\section{Declarations}

Funding Funded by Department of Conservation, BCBC Threatened species grant (WBS D406-976-002) to Bronwen Presswell, a Zoology Department PBRF Research Enhancement grant to Bronwen Presswell, a University of Otago Doctoral Scholarship to Jerusha Bennett, and indirectly by the Marsden Fund (Royal Society of New Zealand: UOO1718).

Conflicts of interest/Competing interests The authors declare no conflict of interest

Availability of data and material Not applicable

Code availability Not applicable

Acknowledgements The authors would like to thank John Darby whose tireless efforts have almost single-handedly conserved the Australasian crested grebe population in New 
Zealand, and who kindly provided our bird specimens, and Robert Poulin for his comments and continued support. Thank you to Liz Girvan of the OCEM for assistance with scanning electron microscopy. In particular the authors would like to thank Dr. Clement Lagrue (DoC) for initiating and facilitating our relationship with the Department of Conservation, and enabling this work to be carried out.

Open Access This article is licensed under a Creative Commons Attribution 4.0 International License, which permits use, sharing, adaptation, distribution and reproduction in any medium or format, as long as you give appropriate credit to the original author(s) and the source, provide a link to the Creative Commons licence, and indicate if changes were made. The images or other third party material in this article are included in the article's Creative Commons licence, unless indicated otherwise in a credit line to the material. If material is not included in the article's Creative Commons licence and your intended use is not permitted by statutory regulation or exceeds the permitted use, you will need to obtain permission directly from the copyright holder. To view a copy of this licence, visit http://creativecommons.org/licenses/by/4.0/.

\section{References}

Baruš, V. \& Zajíček, D. (1967). Parasitic nematodes of birds of the order Colymbiformes in Czechoslovakia. Folia Parasitologia, 14, 73-85.

Baruš, V., Sergejeva, T P., Sonin, M. D. \& Ryzhikov, K. M. (1978). Helminths of fish-eating birds of the Palaearctic region. I Nematoda. The Hague: Springer, pp. 318.

Baruš, V. \& Sergejeva, T. P. (1990). Capillaridiids parasitic in birds in the Palaearctic region. 3. genus Baruscapillaria. Acta Scientiarum Naturalium Brno, 23(3), 1-50.

Blasco-Costa, I., Poulin, R. \& Presswell, B. (2016). Species of Apatemon Szidat, 1928 and Australapatemon Sudarikov, 1959 (Trematoda: Strigeidae) from New Zealand: linking and characterising life cycle stages with morphology and molecules. Parasitology Research, 115, 271-289.

Blasco-Costa, I., Poulin, R. \& Presswell, B. (2017). Morphological description and molecular analyses of Tylodelphys sp.(Trematoda: Diplostomidae) newly recorded from the freshwater fish Gobiomorphus cotidianus (common bully) in New Zealand. Journal of Helminthology, 91, 332-345.

Bondarenko, S. \& Kontrimavichus, V. (2018). Revision of Aploparaksis Clerc, 1903 (Cestoda: Cyclophyllidea, Aploparaksidae), with keys to the species of the genus. Biologija, 64, 1-64.

Bowles, J., Blair, D. \& McManus, D. P. (1992). Genetic variants within the genus Echinococcus identified by mitochondrial DNA sequencing. Molecular andl Biochemical Parasitology, 54, 165-174.

Boyd, E. M. (1966). Observations on nematodes of herons in North America including three new species and new host and state records. Journal of Parasitology, 52(3), 503-511.

Bray, R. A., Gibson, D. I. \& Jones, A. (Eds.) (2008). Keys to the Trematoda. Vol. 3. Wallingford, UK: CABI, pp. 824.

Casalins, L. M., Arbetman, M. P., Viozzi, G. P. \& Flores, V. R. (2020). A new species of Cryptocotyle (Digenea:
Heterophyidae) infecting kelp gull and a galaxiid fish in Patagonian freshwater environments: morphological and molecular analyses. Journal of Parasitology, 106, 203-210.

Cram, E. B. (1927). Bird parasites of the nematode suborders Strongylata, Ascaridata, and Spirurata. Bulletin of the US National Museum, 140, pp. 465.

Creplin, F. C. H. (1825). Observationes de entozois. Greifswald: Moritz Library, pp. 86.

Darby, J. (2021). Grebe Diary (No.13) March 11-17 2021. Wanaka Sun. Wanaka, New Zealand. https://issuu.com/ thewanakasun/docs/11-17_march_2021_1017

Fain, A. (1956). Les schistosomes d'oiseaux du genre Trichobilharzia Skrjabin et Zakharov, 1920, au Ruanda Urundi. Revue de Zoologie et de Botanique Africaines, 54, 147-178.

Faltýnková, A., Gibson, D. I. \& Kostadinova, A. (2008). A revision of Petasiger Dietz, 1909 (Digenea: Echinostomatidae) and a key to its species. Systematic Parasitology, $71,1-40$.

Fuhrmann, O. (1927). Petasiger neocomense nov. sp. Une nouvelle espèce d'Echinostomides. Bulletin de la Société des sciences naturelles de Neuchâtel (Nouvelle série), 1, 3-6.

Galeano, N. A. \& Tanzola, R. D. (2012). Contracaecum ovale (Nematoda: Anisakidae) from Rollandia rolland Quoy \& Gaimard, 1824 (Aves, Podicipedidae) in Argentina. Revista Brasileira de Parasitologia Veterinária 21, 143-147.

Gibbons, L. M. (2010). Keys to the nematode parasites of vertebrates: supplementary volume. Wallingford, UK: CABI, pp. 416.

Gibson, D. I., Jones, A. \& Bray, R. A. (Eds.) (2002). Keys to the Trematoda, Vol.1, Wallingford, UK: CABI. pp. 521.

Harper, J. T. \& Saunders, G. W. (2001). The application of sequences of the ribosomal cistron to the systematics and classification of the florideophyte red algae (Florideophyceae, Rhodophyta). Cahiers de Biologie Marine, 42, 25-38.

Hartwich, G. (1964). Revision der vogelparasitischen Nematoden Mitteleuropas. II. Die Gattung Contracaecum Railliet et Henry, 1912 (Ascaridoidea). Mitteilungen aus dem Zoologischen Museum in Berlin, 40, 15-53.

Jägerskiöld, L. A. (1898). Distomum lingua Creplin: ein Genitalnapftragendes Distomum. Bergens Museums Aarbog, 2, $1-16$.

Jehl, Jr. J. R. (2017). Feather-eating in grebes: A 500-year conundrum. Wilson Journal of Ornithology, 129, 446-458.

Jensen, L. \& Snoyink, R. (2005). The distribution and numbers of Australasian crested grebe (kāmana) in New Zealand, January 2004. Notornis, 52, 34-42.

Johnston, T. H. \& Mawson, P. M. (1949). Some nematodes from Australian hosts, together with a note on Rhabditis allgeni. Transactions of the Royal Society of South Australia, 73, 63-71.

Kamiya, H. \& Ohbayashi, M. (1975). Some helminths of the red fox, Vulpes vulpes schlencki Kishida, in Hokkaido, Japan, with a description of a new trematode, Massaliatrema yamashitai n. sp. Japanese Journal of Veterinary Research, 23, 60-68. 
Khalil, L., Jones, A. \& Bray, R. A. (Eds.) (1994). Keys to the cestode parasites of vertebrates, Wallingford, UK: CABI. pp. 751.

Králová-Hromadová, I., Špakulová, M., Horáčková, E., Turčeková, L., Novobilský, A., Beck, R., Koudela, B., Marinculić, A., Rajský, D. \& Pybus, M. (2001). Sequence analysis of ribosomal and mitochondrial genes of the giant liver fluke Fascioloides magna (Trematoda: Fasciolidae): intraspecific variation and differentiation from Fasciola hepatica. Journal of Parasitology, 94, 58-67.

Linstow, O. (1907). Nematoden aus dem Königlichen Zoologischen Museum in Berlin. Mitteilungen aus dem Zoologischen Museum in Berlin, 3, 251-259.

Macko, J. (1961). Some observations on variability of the species Contracaecum (Contracaecum) nehli Karokhin, 1949. Biologia, 16, 740-748.

Madsen, H. (1945). The species of Capillaria (Nematodes, Trichinelloidea) parasitic in the digestive tract of Danish gallinaceous and anatine game birds, with a revised list of species of Capillaria in birds. Danish review of game biology, 1(1), 1-112.

Mawson, P. M., Angel, M. L. \& Edmonds, S. I. (1986). A checklist of helminths from Australian birds. Records of the South Australian Musueum, 19, 219-325.

McKenna, P. (2010). An updated checklist of helminth and protozoan parasites of birds in New Zealand. Webmed Central Parasitology 1, WMC00705.

Monnig, H. O. (1923). On some new South African parasitic nematodes. Transactions of the Royal Society of South Africa, 11, 105-117.

Moravec, F., Prokopič, J. \& Shlikas, A. V. (1987). The biology of nematodes of the family Capillariidae Neveu-Lemaire, 1936. Folia Parasitologica, 34, 39-56.

Mozgovoi, A. (1953). Principles of nematodology II. Ascaridata of animals and man and the diseases caused by them. Part II. Izdatel'stvo Akad Nauk SSSR: Moscow pp. 8-42

Mutafchiev, Y. \& Georgiev, B. B. (2008). Redescription of Decorataria decorata (Spirurida, Acuariidae) based on nematodes from Podiceps cristatus and P. grisegena (Aves, Podicipediformes) from Bulgaria. Acta Parasitologica, 53, 158-164.

Nadler, S. A. \& Hudspeth, D. S. (2000). Phylogeny of the Ascaridoidea (Nematoda: Ascaridida) based on three genes and morphology: hypotheses of structural and sequence evolution. Journal of Parasitology, 86, 380-393.

Pearson, J. (2008). Heterophyidae. In: [Eds.] Bray, R. A., Gibson, D. I. \& Jones, A. Keys to the Trematoda, Vol. 3 Wallingford, UK: CABI

Presswell, B. \& Bennett, J. (2021). Helminth parasites of shags (Phalacrocoracidae) from the Otago region of southern New Zealand. Journal of Helminthology, 95, e9, 1-18. https://doi.org/10.1017/S0022149X21000031

Presswell, B. \& Blasco-Costa, I. (2020). Description of Tylodelphys darbyi n. sp.(Trematoda: Diplostomidae) from the threatened Australasian crested grebe (Podiceps cristatus australis, Gould 1844) and linking of its life-cycle stages. Journal of Helminthology, 94, 1-8. https://doi.org/ 10.1017/S0022149X19000142

Rind, S. (1974). Some helminth parasites of freshwater birds from the South Island, New Zealand, with particular reference to trematodes of ducks. Mauri ora, 2, 139-146.
Ruehle, B., Presswell, B. \& Bennett, J. (in press). Distribution and diversity of diplostomids in New Zealand. Journal of Parasitology.

Selbach, C., Soldánová, M., Georgieva, S., Kostadinova, A., Kalbe, M. \& Sures, B. (2014). Morphological and molecular data for larval stages of four species of Petasiger Dietz, 1909 (Digenea: Echinostomatidae) with an updated key to the known cercariae from the Palaearctic. Systematic Parasitology, 89, 153-166.

Shamsi, S. (2019). Parasite loss or parasite gain? Story of Contracaecum nematodes in antipodean waters. Parasite epidemiology and control, 4, e00087.

Shamsi, S., Gasser, R., Beveridge, I. \& Shabani, A. A. (2008). Contracaecum pyripapillatum n. sp.(Nematoda: Anisakidae) and a description of C. multipapillatum (von Drasche, 1882) from the Australian pelican, Pelecanus conspicillatus. Parasitology Research, 103, 1031-1039.

Sitko, J. \& Heneberg, P. (2015). Host specificity and seasonality of helminth component communities in central European grebes (Podicipediformes) and loons (Gaviiformes). Parasitology International, 64, 377-388.

Sokolov, S., Protasova, E., Lebedev, D., Gorlacheva, E. \& Gorlachev, V. (2016). Parasites of the Amur sleeper Perccottus glenii Dybowski, 1877 (Actinopterygii: Odontobutidae) in waterbodies of Upper Amur. Parazitologiya, $50,69-81$.

Sokolov, S., Frolov, E., Novokreshchennykh, S. \& Atopkin, D. (2021). An opisthorchiid concept of the genus Liliatrema (Trematoda: Plagiorchiida: Opisthorchioidea): an unexpected systematic position. Zoological Journal of the Linnaean Society, 192, 24-42.

Storer, R. W. (2000). The metazoan parasite fauna of grebes (Aves: Podicipediformes) and its relationship to the birds' biology. Museum of Zoology, University of Michigan, Miscellaneous Publications 188, pp. 90.

Tatonova, Y. V. \& Besprozvannykh, V. V. (2019). Description of a new species, Cryptocotyle lata sp. nov., and discussion of the phylogenetic relationships in Opisthorchioidea. Parasitology International, 72, 101939.

Thaenkham, U., Nawa, Y., Blair, D. \& Pakdee, W. (2011). Confirmation of the paraphyletic relationship between families Opisthorchiidae and Heterophyidae using small and large subunit ribosomal DNA sequences. Parasitology International, 60, 521-523.

Thaenkham, U., Blair, D., Nawa, Y. \& Waikagul, J. (2012). Families Opisthorchiidae and Heterophyidae: are they distinct? Parasitology International, 61, 90-93.

Tkach, V. V., Kudlai, O. \& Kostadinova, A. (2016). Molecular phylogeny and systematics of the Echinostomatoidea Looss, 1899 (Platyhelminthes: Digenea). International Journal for Parasitology, 46, 171-185.

Vasileva, G. P., Georgiev, B. B. \& Genov, T. (1999a). Palaearctic species of the genus Confluaria Ablasov (Cestoda, Hymenolepididae): a redescription and synonymy of C. capillaris (Rudolphi, 1810). Systematic Parasitology, 43, 49-57.

Vasileva, G. P., Georgiev, B. B. \& Genov, T. (1999b). Palaearctic species of the genus Confluaria Ablasov (Cestoda, Hymenolepididae): redescriptions of C. multistriata (Rudolphi, 1810) and C. japonica (Yamaguti, 1935), 
and a description of Confluaria sp. Systematic Parasitology, 44, 87-103.

Vasileva, G. P., Georgiev, B. B. \& Genov, T. (2000). Palaearctic species of the genus Confluaria Ablasov (Cestoda, Hymenolepididae): redescriptions of C. podicipina (Szymanski, 1905) and C. furcifera (Krabbe, 1869), description of $C$. pseudofurcifera n. sp., a key and final comments. Systematic Parasitology, 45, 109-131.

Vasileva, G. P., Kornyushin, V. V. \& Genov, T. (2001). Hymenolepidid cestodes from grebes (Aves, Podicipedidiae) in Ukraine: the genus Confluaria. Vestnik Zoologii, 35, 13-31.

Vasileva, G. P., Gibson, D. I. \& Bray, R. A. (2003). Taxonomic revision of Tatria Kowalewski, 1904 (Cestoda: Amabiliidae): redescriptions of T. biremis Kowalewski, 1904 and T. minor Kowalewski, 1904, and the description of $T$. gulyaevi n. sp. from Palaearctic grebes. Systematic Parasitology, 54(3), 177-198.

Vasileva, G. P., Skirnisson, K. \& Georgiev, B. B. (2008). Cestodes of the horned grebe Podiceps auritus (L.)(Aves: Podicipedidae) from Lake Myvatn, Iceland, with the description of Confluaria islandica n. sp.(Hymenolepididae). Systematic Parasitology, 69, 51-58.

Wood, J. R., Wilmshurst, J. M., Rawlence, N. J., Bonner, K. I., Worthy, T. H., Kinsella, J. M. \& Cooper, A. (2013). A megafauna's microfauna: gastrointestinal parasites of New Zealand's extinct moa (Aves: Dinornithiformes). PLoS ONE 8(2), e57315. doi:https://doi.org/10.1371/journal. pone. 0057315

Yamaguti, S. (1933). Studies on the helminth fauna of Japan. I. Trematodes of birds, reptiles and mammals. Japanese Journal of Zoology, 5, 1-34.

Yamaguti, S. (1941). Studies on the helminth fauna of Japan. Part 36. Avian nematodes, II. Japanese Journal of Zoology, 9, 441-480.

Yamaguti, S. (1958). Systema helminthum. Vol.1. The digenetic trematodes of vertebrates. Pts $1 \& 2$. New York: Interscience Publ. Inc. pp. 1575.

Publisher's Note Springer Nature remains neutral with regard to jurisdictional claims in published maps and institutional affiliations. 